Article

\title{
The Bruneau Woodpile: A Miocene Phosphatized Fossil Wood Locality in Southwestern Idaho, USA
}

\author{
Mike Viney ${ }^{1, *}$, George E. Mustoe ${ }^{2}$ (D), Thomas A. Dillhoff ${ }^{3}$ and Paul K. Link ${ }^{4}$ \\ 1 College of Natural Sciences Education and Outreach Center, Colorado State University, Ft. Collins, \\ CO 80523, USA \\ 2 Geology Department, Western Washington University, Bellingham, WA 98225, USA; mustoeg@wwu.edu \\ 3 Evolving Earth Foundation, P.O. Box 2090, Issaquah, WA 98027, USA; tdillhoff@evolvingearth.org \\ 4 Department of Geosciences, Idaho State University, Pocatello, ID 83209, USA; linkpaul@isu.edu \\ * Correspondence: mike.viney@colostate.edu; Tel.: +1-970-481-0225
}

Received: 3 June 2017; Accepted: 5 September 2017; Published: 9 September 2017

\begin{abstract}
The Bruneau Woodpile site has long been popular among fossil collectors; however, the deposit has received scant attention from scientists. Our research reveals that the fossilized wood was deposited ca. $6.85 \mathrm{Ma}$, within the Chalk Hills Formation, and was mineralized with carbonate-fluorapatite. The diverse assemblage of conifers and hardwoods is representative of the warm temperate forests that flourished in southwest Idaho, USA during the late Miocene. Limb and trunk fragments preserved in a single thin sandstone bed appear to represent woody debris that was transported by streams. One possible explanation is that wood, pumice, and sandy volcaniclastic sediment arrived separately as a result of ordinary stream action, and later were combined into a single assemblage during a subsequent high-energy sedimentation event. We favor an alternate hypothesis: a catastrophic event (e.g., a windstorm) damaged trees on slopes bordering the ancient lake. Branches and small trunk fragments were carried by wind and rain into local streams and ponds where they became waterlogged. After a delay that allowed pumice and wood to become saturated, storm water transported these materials, along with finer volcaniclastic sediment, into a lake. The resulting density current produced a fining-upward sedimentary cycle where wood was preserved in the lowest, coarsest stratum.
\end{abstract}

Keywords: apatite; carbonate-fluorapatite; Chalk Hills Formation; Chalk Hills Lake; ancient Lake Idaho; Idaho; Mount Saint Helens; Snake River Plain; phosphatized wood; paleobotany; Bruneau Woodpile; petrified wood

\section{Introduction}

The Bruneau Woodpile is an informal name used by petrified wood aficionados to describe a fossil collecting locality in southwest Idaho, approximately $20 \mathrm{~km}$ south of the town of Bruneau (Figure 1 [1]). This long-accepted terminology is confusing because the Bruneau Formation, is a younger (Pleistocene) stratigraphic unit; Bruneau Woodpile occurs in strata of the late Miocene Chalk Hills Formation (Figure 2 [2]). Located near the town of Bruneau, Idaho, the site preserves abundant petrified wood in the form of limbs and driftwood mineralized with carbonate-fluorapatite. The fossil wood assemblage contains a diverse mix of at least 15 angiosperm and gymnosperm types. Taxonomic affinities of the Bruneau Woodpile specimens supplement pollen and leaf studies of similar aged deposits that help establish the vegetative types making up late Miocene ecosystems of southwest Idaho [3-6]. This is the first scientific investigation that provides a comprehensive overview of this unusual North American fossil wood locality. Our research focuses on two puzzling aspects: the occurrence of limb and small wood fragments in a single stratum within a stratigraphic section that otherwise contains no petrified wood, and the phosphatic mineralization of wood. 


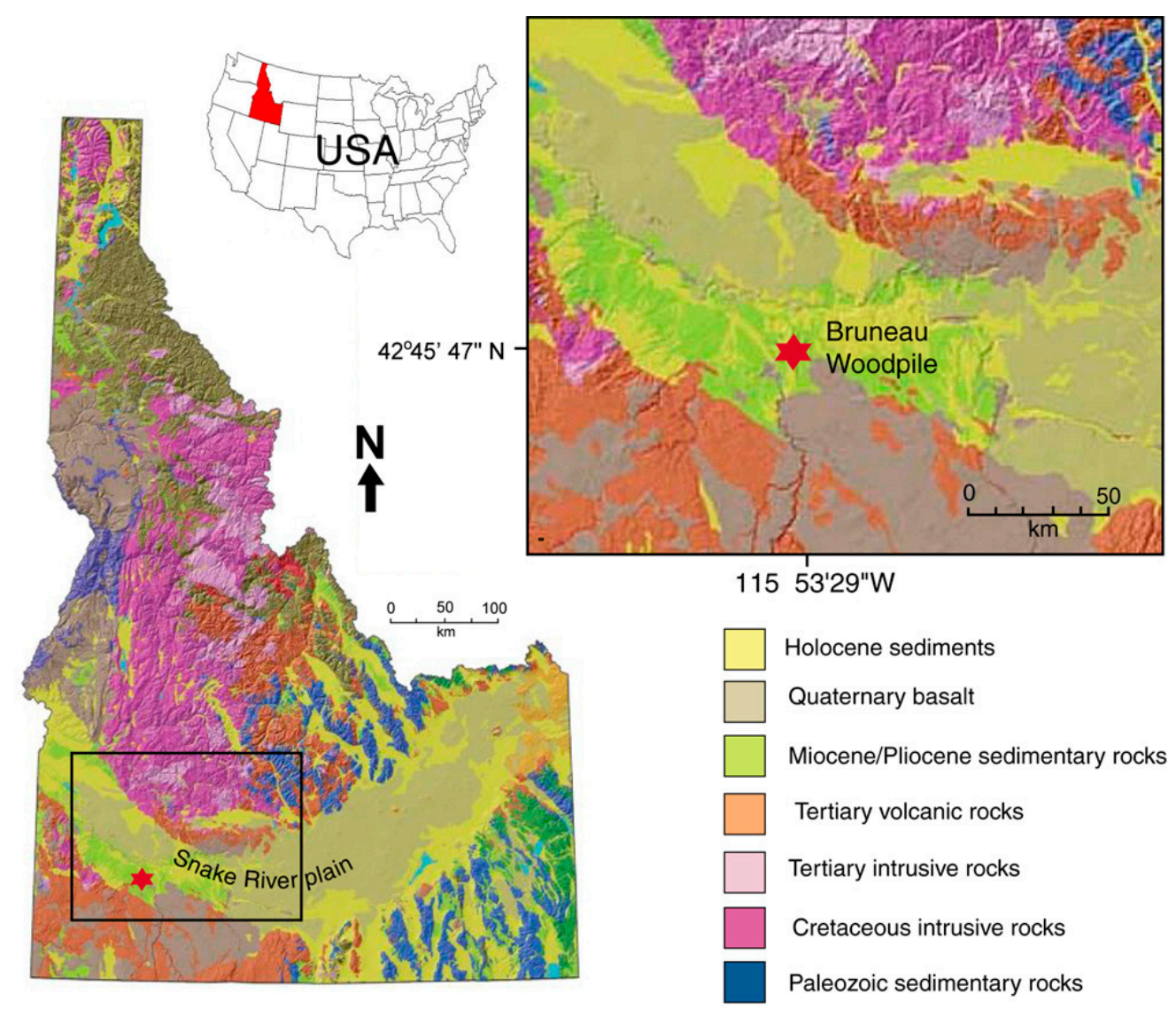

Figure 1. Location map adapted from Lewis et al. [1].

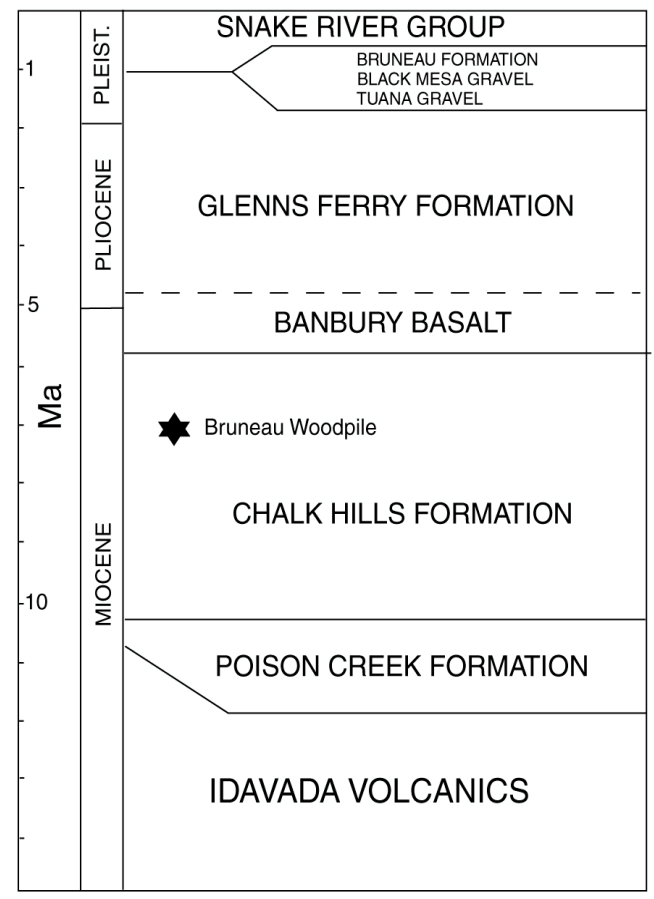

Figure 2. Generalized Stratigraphic Section [2]. 


\subsection{Previous Work}

In the late 1960s, Lt. Col. Quincy D. Howell and J. V. Root enlisted the help of members of the Gem Club of Boise to identify fossil wood from Bruneau Woodpile and other sites in southern Idaho and eastern Oregon. This group published their findings in the October 1971 issue of Gems and Minerals [7]. They concluded that the wood had washed into an ancient lake during the late Pliocene. In the absence of analytical data, the petrified wood was presumed to consist of calcium sulfate $\left(\mathrm{CaSO}_{4}\right)$ and calcium carbonate $\left(\mathrm{CaCO}_{3}\right)$. While polished transverse wood sections were used to investigate taxonomic affinities of the Bruneau Woodpile assemblage, corroboration based on microscopic thin sections was not attained until now. Individual taxa have been previously described from the Bruneau Woodpile, including a bracket fungus [8] and pine cones [9]. Our investigation is a long-delayed successor to the work begun by the original Bruneau Woodpile study group.

\subsection{Geologic Setting}

The Bruneau Woodpile is located in the western Snake River Plain, a broad arcuate depression that extends across southern Idaho, USA. The Neogene volcanic history of southern Idaho was dictated by the passage of the North American Plate over a stationary mantle plume that is currently situated beneath Yellowstone National Park, Wyoming [10]. The western part of the Snake River Plain is a NW trending fault-bounded graben, while the eastern part is a structural downwarp created by the weight of overlying volcanic and sedimentary rocks interacting with the formation of a mid-crustal sill and thermal contraction after passage over the plume-generated hotspot [11]. The western section contains extensive rhyolitic tuffs and ash flows of the Miocene Idavada Volcanic Group, ranging in age from 15 to $11 \mathrm{Ma}[12,13]$.

These volcanic materials are overlain by younger mafic volcanic rocks and fluvial and lacustrine sediments (Chalk Hills and Glenns Ferry formations) that contain volcanic and hyaloclastic interbeds (Figures 2 and 3). Sedimentation began at approximately $9 \mathrm{Ma}$, when several lakes developed. One of these was Chalk Hills Lake, in which the Bruneau Woodpile sediments were deposited. These lakes expanded and retreated in size, eventually coalescing to form a single enormous lake, ancient Lake Idaho (represented by the Glenns Ferry Formation, Figure 2), which ultimately extended over an area of several thousand $\mathrm{km}^{2}[2,14]$. During the next 6.5 million years, thick basin-fill sediment accumulated in the lake basin. This sediment contains material eroded from nearby mountain ranges, as well as rhyolitic tephra. These sediments locally preserve plant and animal fossils.

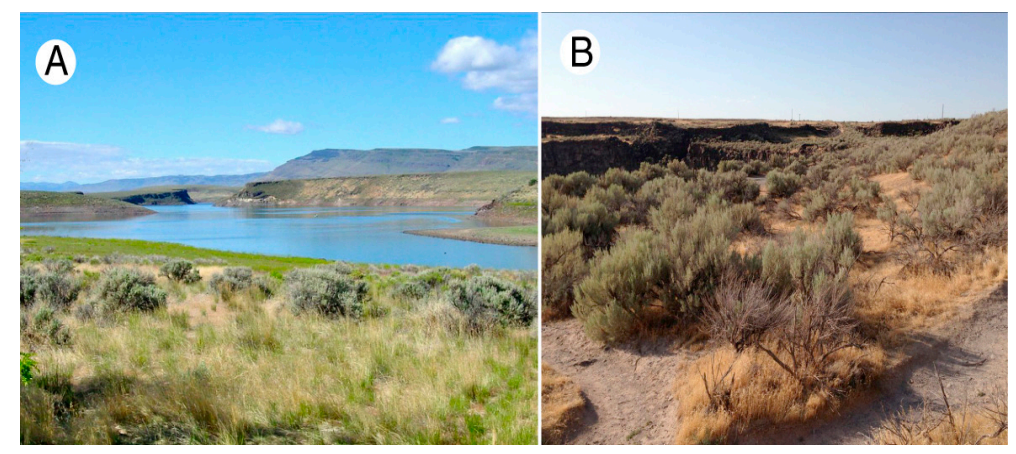

Figure 3. Modern views of the Snake River Plain, near Salmon Falls (A) and Shoshone Falls (B); Idaho USA.

The petrified wood assemblage investigated in our study is preserved in lacustrine sediments of the Chalk Hills Formation. This Miocene-age lake is here referred to as the Chalk Hills Lake to distinguish it from the Pliocene ancient Lake Idaho. Other important Snake River Plain fossil sites include the late Miocene Pickett Creek leaf and pollen deposit [6] and the Hagerman Fossil Beds National Monument, where Pliocene strata preserve a multitude of vertebrate fossils [15]. 


\subsection{Paleoenvironment}

Southern Idaho is now an arid region where extensive lower elevations are sagebrush steppe flora, bordered by barren mountains (Figure 3). The region typically receives less than $250 \mathrm{~mm}$ of rain each year, with temperatures that range from $-34{ }^{\circ} \mathrm{C}$ in winter to $43{ }^{\circ} \mathrm{C}$ in summer [5].

Neogene environmental conditions were very different. By the late Miocene lakes occupied a large area of southern Idaho, eventually expanding in the Pliocene to produce ancient Lake Idaho; the origin of which was related to formation of the western Snake River Plain graben [16]. Topography of the surrounding watershed was relatively gentle; much of the lakebed sediment consists of small pebble to clay-sized fractions transported by local stream tributaries as well as larger rivers. Lake levels fluctuated over time, due to both tectonic and climatic changes. Ultimately, ancient Lake Idaho drained when the outlet river incised Hells Canyon, breaching the lake basin. In place of the ancient lake, the Snake River now traverses southern Idaho [17,18].

The late Miocene Chalk Hills Formation, host to the Bruneau Woodpile, represents a time when Pacific Northwest forests were more uniform and more widespread than today, in large part because the Cascade Range had not yet reached an elevation sufficient to cause a pronounced rain shadow. The Chalk Hills Formation paleoflora originated during the late Miocene, when the northwest climate was transitioning from the warm, humid regime of the middle Miocene to the more arid, summer-dry climate of today. Low elevation forests bore a resemblance to the modern broadleaved hardwood forests of north central USA. Annual precipitation was in the range of $1200-1300 \mathrm{~mm}$, with a mean annual temperature of approximately $13.5^{\circ} \mathrm{C}$ [5]. Analyses of fossil pollen show Pinus as the dominant conifer, but Abies, Picea, and Tsuga were present. Deciduous trees were abundant and taxonomically diverse [3,5]. The Pickett Creek leaf and pollen deposit [6] of the Chalk Hills Formation documents a flora with a high incidence of summer-dry tolerant species, including white oaks, evergreen oaks, pine and legumes, similar to the wood types found in the Bruneau Woodpile assemblage.

The lake sediments also preserve fish remains that include cold water salmon and trout and warm water sunfish and catfish, indicative of warm, moist climate with cool summers and mild winters [19,20]. Two fish taxa, Mylocheilus inflexus (a minnow) and Paleolox larsonia (a salmon) found in the Chalk Hills Formation do not occur in the overlying lacustrine sediments of the Pliocene Glenns Ferry Formation [2]. Chalk Hills Formation strata also preserve remains of beaver, rhinoceros, camel, horse, sloth, and various molluscs [19].

By the mid Pliocene, the development of the Cascade Range rain shadow [5] and global climatic change [21] profoundly altered the flora and fauna of the Snake River Plain. Temperate forests were replaced by pine/oak woodlands with areas of grassland. The mid-Pliocene climate was drier, with perhaps half the annual rainfall of the Chalk Hills Formation. Lake shore, ponds, open woodlands and grasslands were inhabited by a diverse vertebrate fauna that included swans, grebes, and other water birds, rodents, mustelids, saber-tooth tigers, camels, and horses [14]. The Pleistocene brought increased aridity to the Snake River Plain. By 1.3 Ma, annual rainfall had decreased to approximately $250 \mathrm{~mm}$, and the landscape became dominated by sagebrush (Artemisia), saltbush (Sarcobatus) and grasses, i.e., semi-desert sagebrush/bunchgrass steppe flora that flourishes in modern times [5] (Figure 3).

\section{Methods and Materials}

SEM/EDS images were obtained for 10 specimens using a Vega Tescan SEM (Tescan, Brno, Czech Republic) equipped with an EDAX Genesis XRF spectrometer (EDAX, Mahwah, NJ, USA). X-ray diffraction (XRD) patterns were made for two specimens with a Rigaku Geigerflex diffractometer using Ni-filtered $\mathrm{Cu} \mathrm{K}-\alpha$ radiation. Tephra geochronology is based on electron microprobe analysis of Bruneau Woodpile volcanic ash collected by Paul Link, using the elemental data to correlate the tephra with previously-analyzed specimens from other Snake River Plain strata of known radiometric age. Glass shards recovered from a vitric ash bed at the Bruneau Woodpile site were analyzed using electron 
microprobe by B.P. Nash (University of Utah, UT, USA) who interpolated the age by chemostratigraphic comparison with western North American vitric tuffs spanning 16 to 6 Ma [22].

Fossil wood thin sections were prepared using standard techniques and examined and photographed using a Nikon Eclipse 50i microscope (Nikon, Tokyo, Japan) coupled with a Nikon DS-Fi1 camera. Thin sections described in this study were deposited at the University of Washington Burke Museum in Seattle, WA, USA. Identifications were aided by standard references, including the Textbook of Wood Technology [23] and the InsideWood image database [24].

\section{Results}

\subsection{Site Description}

The wood-bearing beds occur at near-surface depths at several localities, where collecting has been popular since the 1950s $[7,25]$. Our research was conducted at a site accessible via several $\mathrm{km}$ of rough dirt road at coordinates of $42^{\circ} 45^{\prime} 47.19^{\prime \prime} \mathrm{N}, 115^{\circ} 53^{\prime} 29.46^{\prime \prime} \mathrm{W}$.

Phosphatized wood is preserved in a sandy bed that marks the bottom of a $15 \mathrm{~cm}$ thick fining-upward sequence (Figure 4). Specimens are abundant for those who are willing to first remove more than a meter of partially-cemented sediment to reach the wood-bearing stratum (Figures 5-7). The stratum is rich in volcanic material that includes numerous pumice clasts and obsidian granules in a fine tephra-rich matrix (Figure 7) containing well-rounded, moderately well-sorted quartz grains of similar size and shape to equally abundant obsidian granules. Disarticulated fish bones are sparsely distributed within the wood-bearing stratum.

The majority of fossil wood specimens are elongated limbs or irregular fragments of trunk wood that have characteristics indicative of fluvial transport. Exterior surfaces have been smoothed by erosion, bark and side branches have been removed, and terminations are rounded (Figure 8). The wood-bearing bed is overlain by a light gray layer of white fine sand with parallel laminations, capped by a thin layer of whitish silt. This interval completes the first fining-upward sequence. A second, 30-cm upward fining succession begins with a bed of cross bedded vitric ash that passes upward to rippled ash and to massive white argillaceous siltstone. The second upward fining sequence is overlain by a brown cemented layer and a massive white clay. Above that is a fallout ash layer consisting of gray fine pumice sand and vitric gray rhyolitic ash. Geochemical analysis and correlation suggests that this younger ash layer can be assigned a chemostratigraphic age of $6.84 \pm 0.05 \mathrm{Ma}$ (late Miocene) [26].

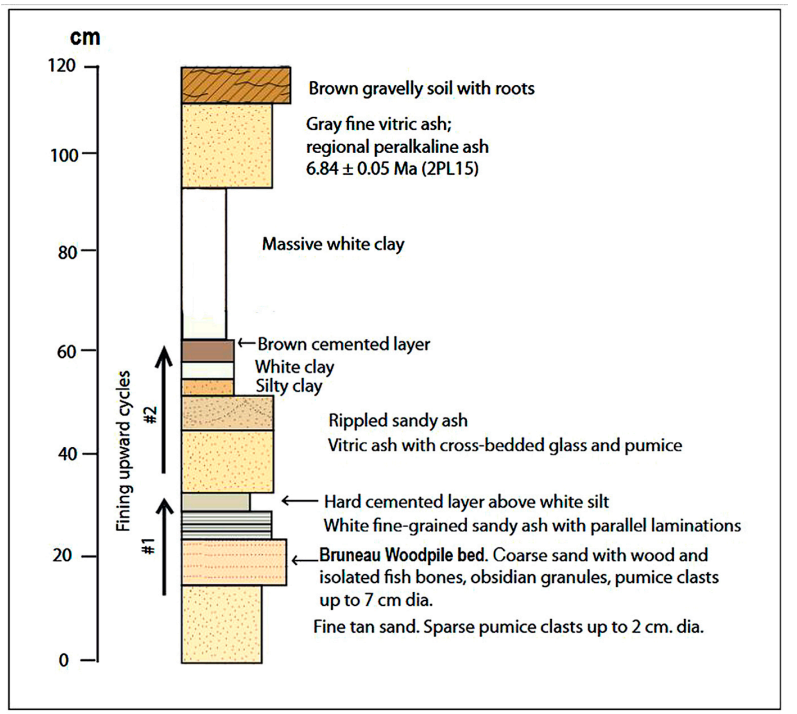

Figure 4. Generalized stratigraphic section of the Chalk Hills Formation beds at Bruneau Woodpile locality. 


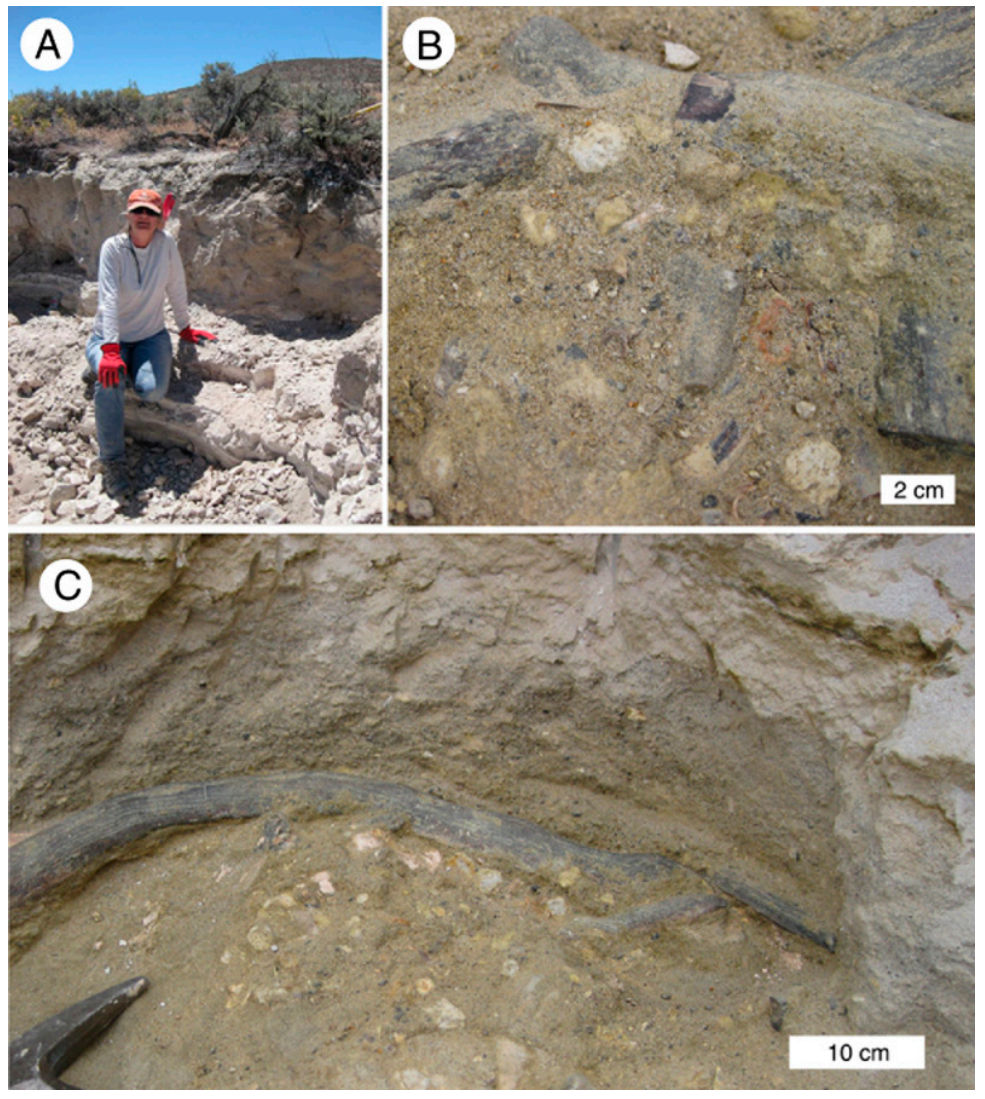

Figure 5. Bruneau Woodpile site. (A) Revealing the wood-bearing stratum requires excavation of one meter of cemented sediment; (B) Limb sections and trunk fragments occur in a weakly cemented sandstone bed that contains large pumice clasts. Some wood specimens have a thin black exterior coating composed of manganese oxide, as evidenced by SEM/EDS analysis; (C) The wood-bearing layer is overlain by a $\sim 7 \mathrm{~cm}$ white fine sandy ash with parallel laminations. Note the abundance of pumice clasts in the sandy sediment below the elongate fossil twig.

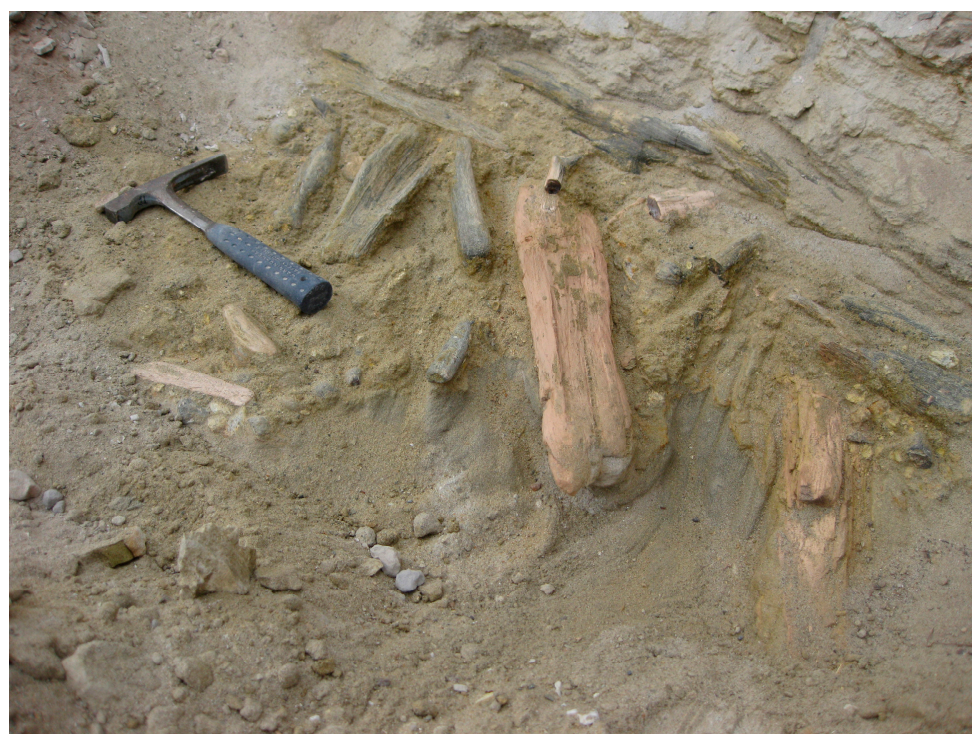

Figure 6. Phosphatized wood at the Bruneau Woodpile site. Elongate limbs and larger wood fragments are positioned in different orientations. 


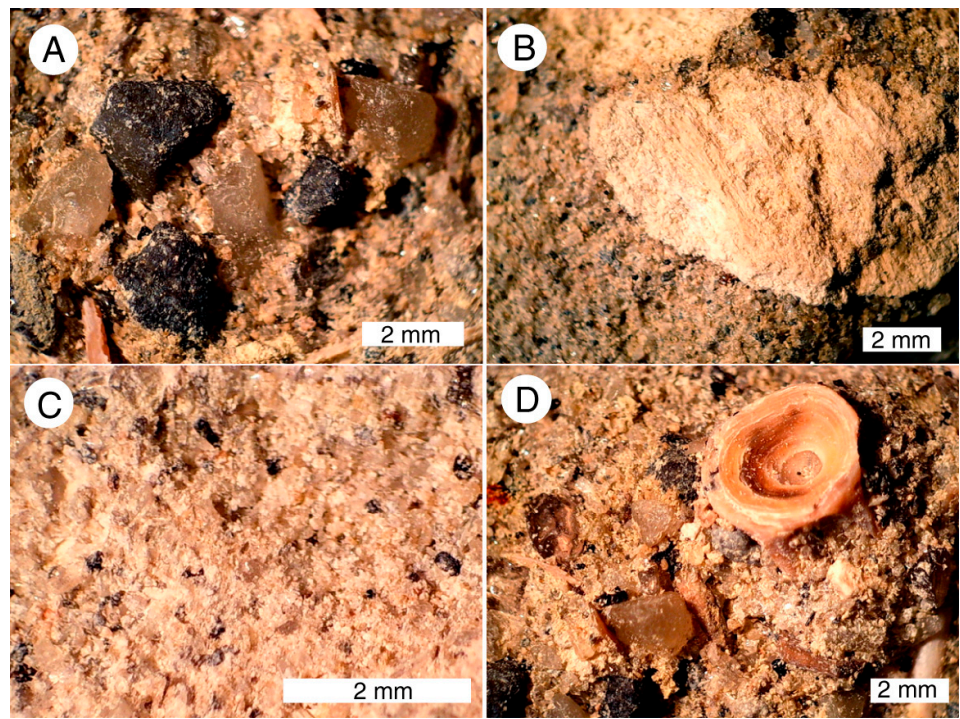

Figure 7. Bruneau Woodpile sedimentology. (A,B) are sediments from wood-bearing stratum. (A) Black obsidian granules and translucent gray quartz grain; (B) Pumice clast; (C) fine-grained ash-rich bed that overlies wood-bearing stratum; (D) fish vertebra in sandy sediment containing quartz and obsidian granules.

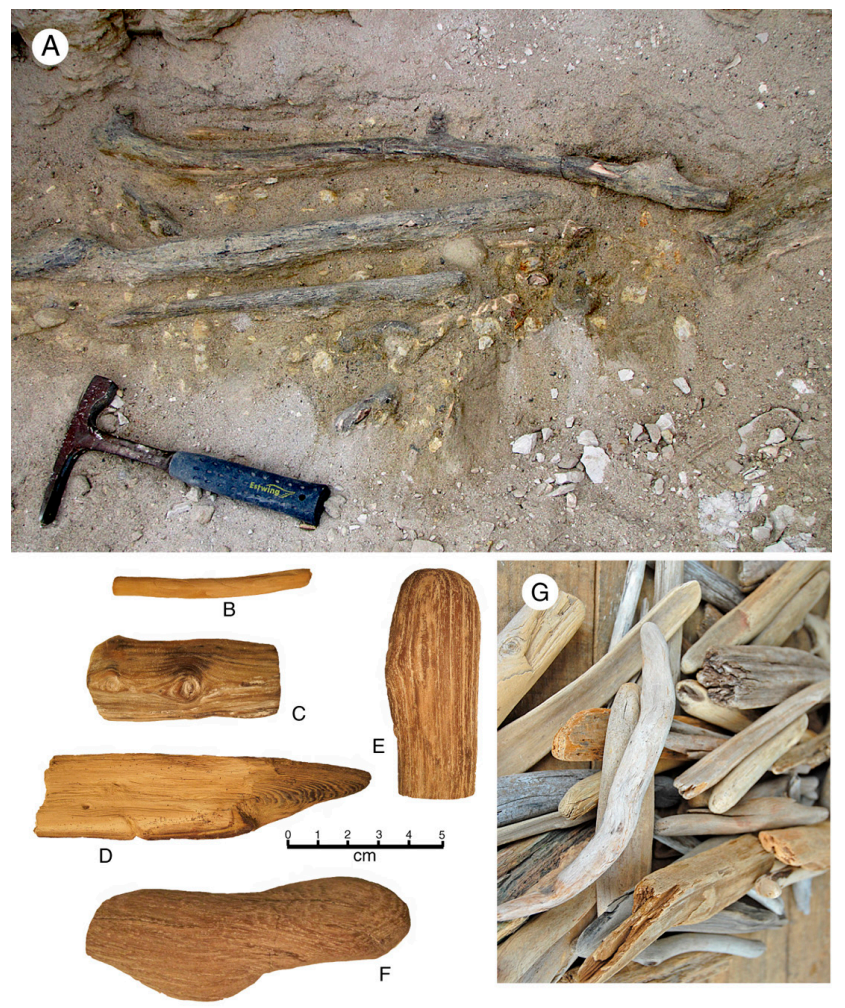

Figure 8. Bruneau Woodpile specimens have characteristics indicative of fluvial transport. Two morphotypes are common: elongate limbs (A-C) and irregular fragments of trunk wood (D-F). For both types, exterior surfaces have been smoothed by erosion, bark and side branches have been removed, and terminations are rounded. Elongate limbs (A) break into shorter segments during excavation from the matrix because of the brittleness of the phosphatized wood. These morphologies are identical to modern fluvial driftwood $(\mathbf{G})$. 


\subsection{Age}

The Bruneau Woodpile was originally assigned a late Pliocene age [7]. Geochemical analysis [26] of rhyolitic glass shards in the tuff bed $\sim 80 \mathrm{~cm}$ above the wood bed (stratigraphic location of sample shown in (Figure 4), matches an unnamed peralkaline ash bed below the Blacktail Creek Tuff [27] from the Heise volcanic field of the eastern Snake River Plain. The Blacktail Creek Tuff is $6.61 \pm 0.01 \mathrm{Ma}$ (Ar-Ar age from welded ash of sample PTH4 [28]). Our sample of the unnamed ash $80 \mathrm{~cm}$ above the Bruneau Woodpile bed was chemostratigraphically correlated by B.P. Nash (University of Utah) to an age of $6.84 \pm 0.05 \mathrm{Ma}$ [26]. Based on these dates, the Bruneau Woodpile occurs in the Chalk Hills Formation (late Miocene) [29].

\subsection{Mineralogy and Geochemistry}

While the Bruneau Woodpile fossil wood specimens have long been identified as being mineralized with calcium carbonate or calcium sulfate [7], new analytical data reveal that the mineralization is phosphatic.

X-ray diffraction patterns (Figure 9) show that the only discernable crystalline phase is a member of the apatite family, comprising members that fall within the general formula of $\mathrm{Ca}_{5}\left(\mathrm{PO}_{4}\right)_{3}(\mathrm{~F}, \mathrm{OH}, \mathrm{Cl})[30,31]$. The three members, fluorapatite, hydroxylapatite, and chlorapatite are not easily distinguishable from XRD data, but SEM/EDS spectra (Figure 10) show that fluorine is present at levels of $\sim 1 \%$ by weight. $\mathrm{Cl}$ is below detection limits, and the inability of EDS to detect $\mathrm{H}$ and poor quantification of $\mathrm{O}$ prevent recognition of $\mathrm{OH}^{-}$. However, the presence of a significant fluorine spectral peak suggests that calcium phosphate is present as fluorapatite, which is sometimes given the mineral name francolite.

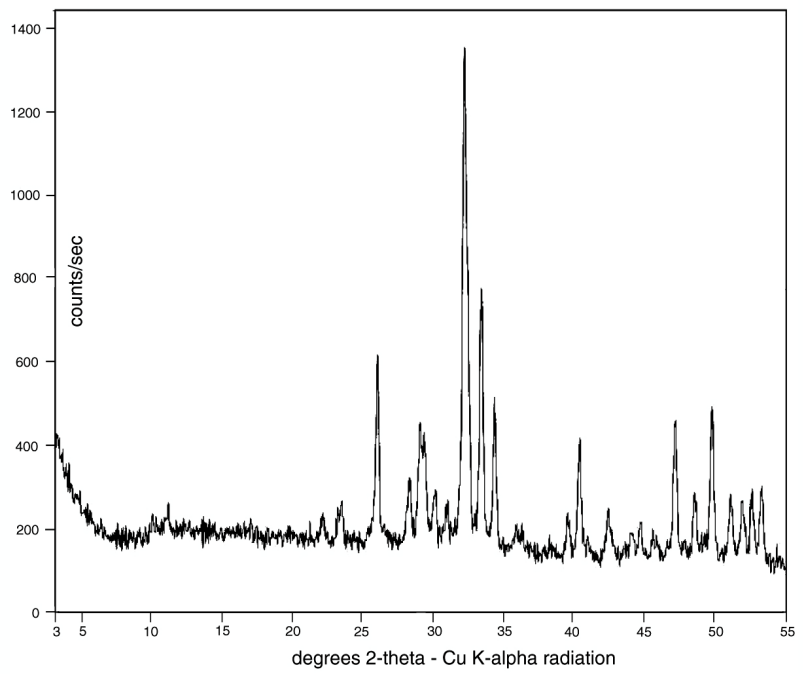

Figure 9. X-ray diffraction (XRD) pattern. All peaks are from an apatite group mineral.

The large carbon peak in the SEM/EDS spectrum (Figure 10) suggests that the mineralization is carbonate-fluorapatite. The $450^{\circ} \mathrm{C}$ LOI (loss on ignition) (Table 1) indicates an organic carbon content of several percent, but the EDS spectrum was obtained from microcrystalline material within a vessel lumen, where the analyzed material was separated from any possible relict organic matter in the cell walls. This occurrence is evidence that carbon is present as an inorganic constituent within the phosphatic structure. Carbonate-fluorapatite results from the partial substitution of $\mathrm{CO}_{3}{ }^{-2}$ in place of $\mathrm{PO}_{4}{ }^{-3}$, equivalent to a generalized formula of $\mathrm{Ca}_{5}\left(\mathrm{PO}_{4}, \mathrm{CO}_{3}\right)_{3}(\mathrm{~F}, \mathrm{OH}, \mathrm{Cl})[30]$.

The amount of carbonate in carbonate-fluorapatite can be estimated based on major element geochemistry (Table 2). Carbon concentrations cannot be accurately estimated by SEM/EDS spectrometry because of the element's low atomic mass that makes it undetectable by 
wavelength-dispersive XRF spectrometry. However, when wt. \% values are recalculated as atomic \% values, the ratio of Ca:P provides an important compositional indication (Table 2). For pure apatite, the $\mathrm{Ca}: \mathrm{P}$ proportion is 1.67. A Ca:P ratio that exceeds this value provides evidence that the mineral is deficient in $\mathrm{P}$, suggesting that $\mathrm{CO}_{3}$ is present in an amount sufficient to provide a neutral molecular structure. Both Bruneau Woodpile samples have ratios that exceed that of ideal apatite, substantiating the existence of a carbonate component. For this reason, we identify the mineralizing material of the Bruneau Woodpile fossil wood specimens as carbonate-fluorapatite. The small amount of $\mathrm{SiO}_{2}$ may be caused by substitution of silica for phosphorus in the mineral structure; the absence of quartz or other silicate mineral peaks in the XRD pattern (Figure 9) suggests that Si is not present as a secondary mineral phase.

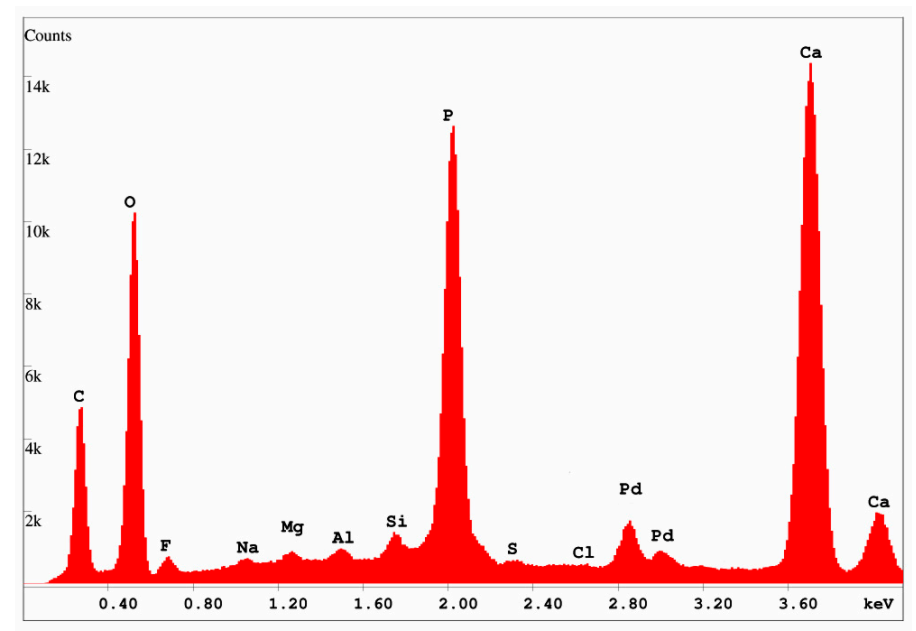

Figure 10. SEM/EDS spectrum, $15 \mathrm{KeV}$. Pd peaks are spectral artifacts from sputter-coating the specimen with $\mathrm{Pd}$ to provide electrical conductivity. Calculated fluorine content $=1.03 \mathrm{wt}$. $\%(=1.11$ atomic $\%)$; chlorine content $=0.0 \mathrm{wt}$. $\%$ (= 0.0 atomic $\%)$.

Table 1. Major element analysis by X-ray Fluorescence Spectrometry. Elemental results are calculated as wt. \% oxide.

\begin{tabular}{|c|c|c|c|c|c|c|c|c|c|c|c|}
\hline Sample & $\mathrm{SiO}_{2}$ & $\mathrm{Al}_{2} \mathrm{O}_{3}$ & $\mathrm{TiO}_{2}$ & $\mathrm{Fe}_{2} \mathrm{O}_{3} *$ & $\mathrm{MnO}$ & $\mathrm{MgO}$ & $\mathrm{CaO}$ & $\mathrm{K}_{2} \mathrm{O}$ & $\mathrm{Na}_{2} \mathrm{O}$ & $\mathrm{P}_{2} \mathrm{O}_{5}$ & LOI ** \\
\hline 1 & 14.53 & 0.12 & 0.00 & 1.88 & 0.45 & 0.98 & 44.36 & 0.01 & 0.94 & 37.79 & 3.83 \\
\hline 2 & 13.69 & 0.04 & 0.00 & 1.73 & 0.50 & 0.55 & 45.67 & 0.00 & 0.00 & 33.33 & 5.83 \\
\hline
\end{tabular}

Table 2. Conversion of $\%$ oxide values to atomic $\%$, and calculated Ca:P ratios.

\begin{tabular}{cccccc}
\hline \multirow{2}{*}{ Sample } & \multicolumn{2}{c}{ Weight $\%$} & \multicolumn{2}{c}{ Atomic \% } & \multirow{2}{*}{$\begin{array}{c}\text { Ca:P } \\
\text { Ratio }\end{array}$} \\
\cline { 2 - 4 } & $\mathbf{C a O}$ & $\mathbf{P}_{\mathbf{2}} \mathbf{O}_{5}$ & $\mathbf{C a}$ & $\mathbf{P}$ & \\
\hline 1 & 44.36 & 37.79 & 31.72 & 16.48 & 1.92 \\
2 & 45.67 & 33.33 & 32.65 & 14.53 & 2.25 \\
\hline \multicolumn{4}{c}{ Ideal formula: $\mathrm{Ca}_{5}\left(\mathrm{PO}_{4}\right)_{3} \mathrm{Ca}: \mathrm{P}=5: 3=1.67}$. \\
\end{tabular}

High magnification images (Figure 11) show that the carbonate-fluorapatite is present in crystalline form, consistent with the strong peaks observed in the XRD pattern (Figure 9). No relict organic matter is visible; anatomical features are preserved as inorganic replacements. Quality of anatomical preservation is variable. Many specimens show preserved cellular features (Figure 12). Features of a few specimens include spiral fibril patterns in the middle cell wall (Figure 12B,C), evidence of trees that have anatomical asymmetry because of oblique gravitational forces, e.g., a tree 
growing on a slope, or on branched limbs [23]. One specimen (Figure 12D) shows evidence of microbes that bored branched galleries in the exterior surface. Possible organisms include cyanobacteria, algae, and fungi. These microbes are known to penetrate the phosphate-enriched skeletons of corals as a source of phosphorus, a macronutrient that is often scarce in pristine natural environments [32]. Chemolithotrophic bacteria are also a possibility, particularly phosphobacteria, which use phosphorus reduction as a source of metabolic energy [33].

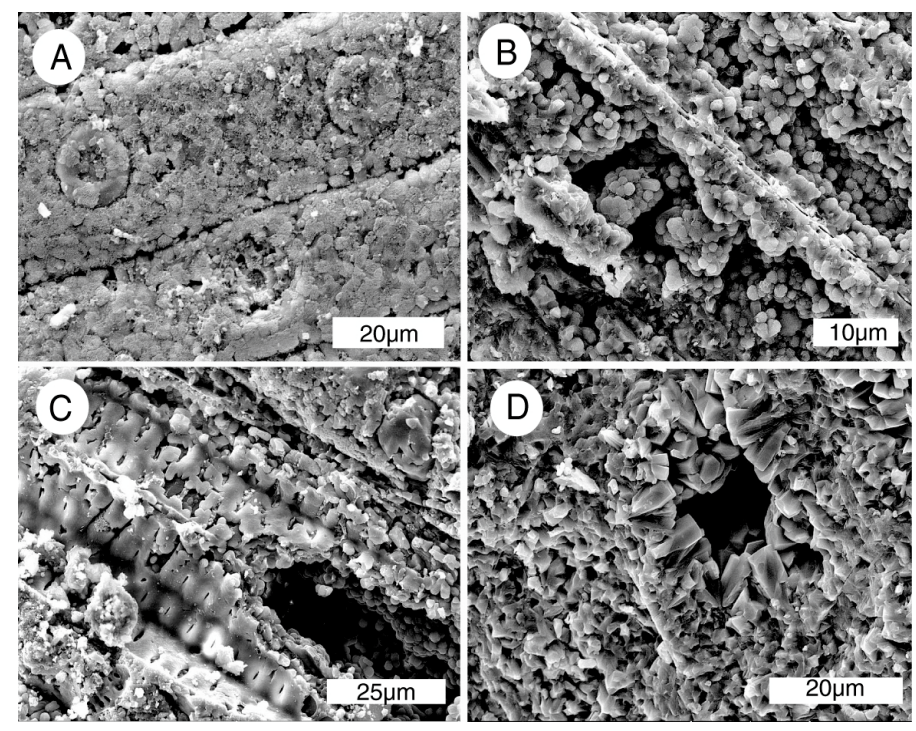

Figure 11. SEM photomicrographs of Bruneau Woodpile wood show microcrystalline structure of carbonate-fluorapatite. (A) Longitudinal view of two tracheids showing circular pits; (B) Fractured cell walls of a tracheid; (C) Interior surface of a tracheid showing numerous pit apertures; (D) Carbonate-fluorapatite crystals bordering a pit aperture.

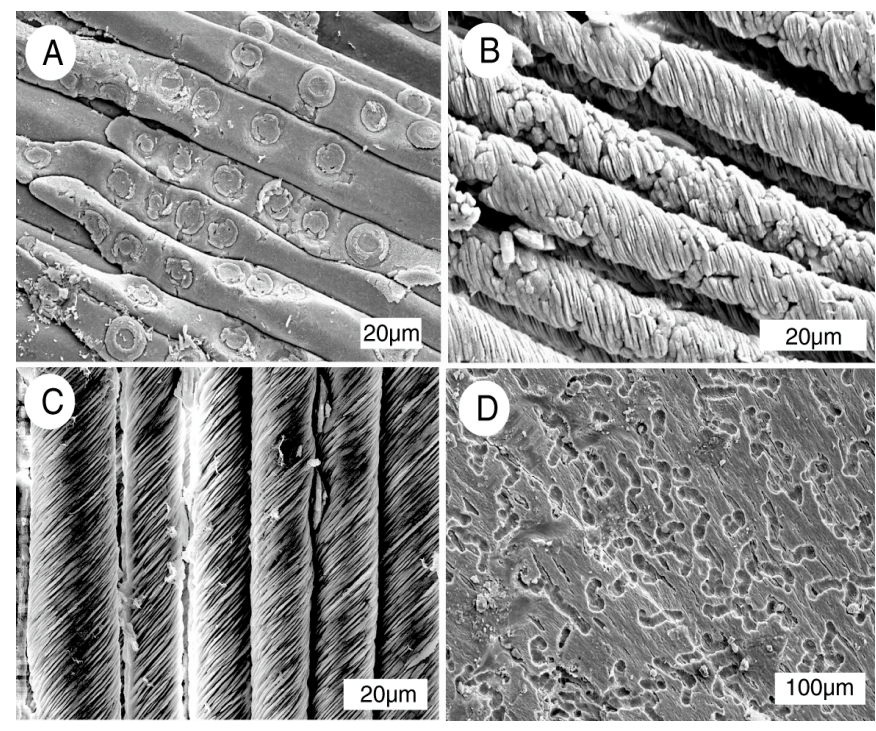

Figure 12. SEM images of Bruneau Woodpile specimens. (A) Conifer wood, radial orientation, showing tracheids with well-preserved bordered pits; (B,C) Radial view of specimens of reaction wood, where tracheids have spiral architecture in the secondary cell wall; (D) Exterior surface of this limb shows galleries produced in the mineralized wood by chemolithotrophic microbes (see text for discussion). 


\subsection{Paleobotany}

Taxonomic information from fossil wood collected at the Bruneau Woodpile is limited due to poor anatomical preservation, especially in the radial and tangential sections. Even so, a number of types can be assigned to family or genus based on available features. The best representatives of each type were selected for sectioning from more than 200 specimens. Larger images and anatomical descriptions are provided in Supplement 1. Taxa recognized from the Bruneau Woodpile are as follows (Figure 13):

Conifers

- Cupressaceae

- Pinaceae

Piceoxylon (Spruce/Douglas fir type)

Pinus sp. (Pine)

Angiosperms

- Berberidaceae

cf. Berberis (Barberry/Oregon grape type)

- Fabaceae

cf. Robinia (Black locust type)

- Fagaceae

Quercus sp. (White oak group)

Quercus/Lithocarpus (Live oak group)

- Juglandaceae

Carya sp. (True hickory type)

- cf. Salicaceae

Populus/Salix (Poplar/willow type)

- Sapindaceae

Acer sp. (Soft maple group)

- Ulmaceae

Ulmus sp. (Elm)

- Undetermined angiosperms

Undetermined hardwood 1

Undetermined hardwood 2

Undetermined hardwood 3

Undetermined hardwood 4 


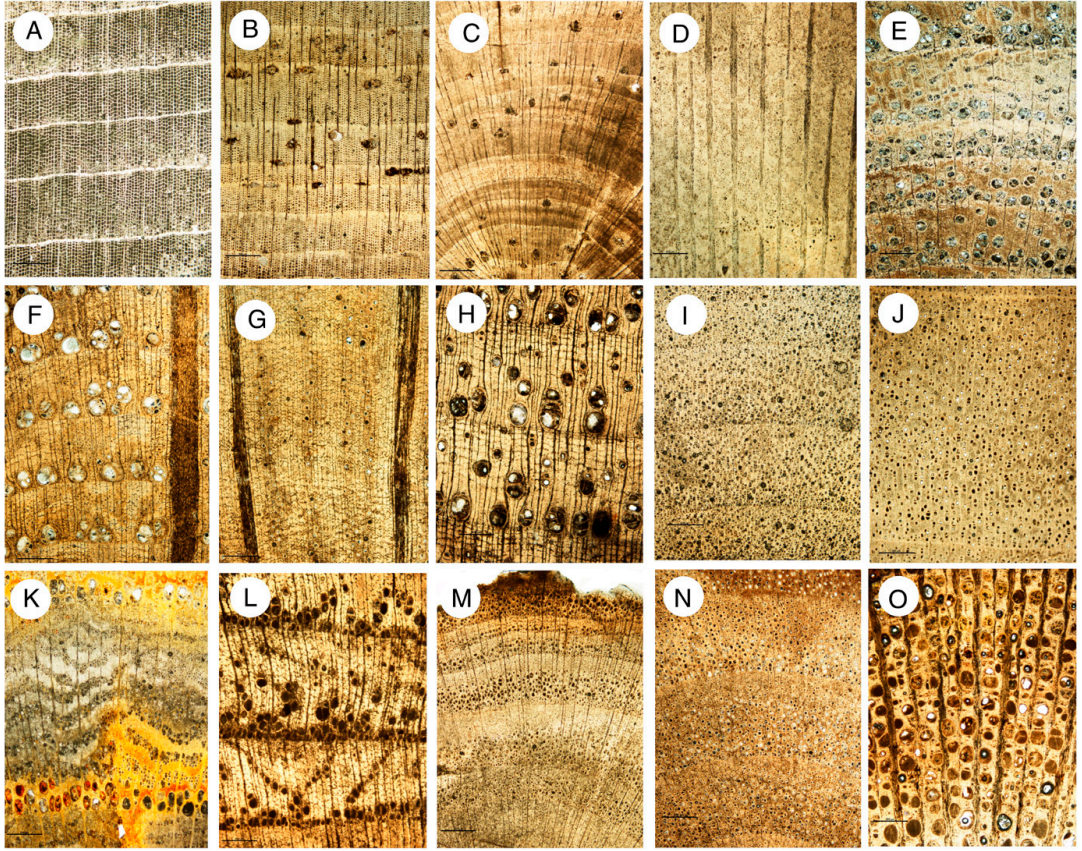

Figure 13. Fossil wood types from the Bruneau Woodpile (University of Washington Burke Museum specimen numbers in parentheses). (A) Cupressaceae (UWBM PB98590); (B) Piceoxylon (UWBM PB98565); (C) Pinus sp. (UWBM PB98568); (D) cf. Berberis (UWBM PB98560) (E) cf. Robinia (UWBM PB98587); (F) Quercus sp. (UWBM PB98591); (G) Quercus/Lithocarpus (UWBM PB98589); (H) Carya sp. (UWBM PB98577); (I) cf. Salicaceae (UWBM PB98557); (J) Acer sp. (UWBM PB98558); (K) Ulmus sp. (UWBM PB98559); (L) Undetermined hardwood \#1 (UWBM PB98567); (M) Undetermined hardwood \#2 (UWBM PB98570); (N) Undetermined hardwood \#3 (UWBM PB98576); (O) Undetermined hardwood \#4 (UWBM PB98556).

\section{Discussion}

\subsection{Taphonomy and Sedimentology}

The origin of the Bruneau Woodpile can be considered using a multiple working hypotheses approach, considering two alternatives. Hypothesis 1: Fossilized wood originated from normal processes of fluvial transport and lacustrine deposition. This scenario involves the wood and sediment being delivered separately to the lake. They were, subsequently reworked into a single bed. Hypothesis 2: Fossilized wood resulted from an unusual event, when limbs and wood fragments from catastrophically damaged trees were transported and deposited with pumice and obsidian in a single bed. These hypotheses are considered with respect to stratigraphic, sedimentologic, and paleontologic features of the site.

A brief review of the depositional characteristics are in order. At Bruneau Woodpile, fossilized limbs and small trunk fragments occur in the basal unit of a fining-upward sequence. This mode of occurrence is very different from a typical lacustrine lahar deposit, where wood occurs in fine-grained strata at the top of a graded sequence (Figure 14). At Bruneau Woodpile, the fossil wood comprises limbs and small trunk fragments stripped of their bark-both types having abraded driftwood-like shapes with tapered ends. This morphology is evidence that the wood had undergone fluvial transport. Fossil wood is present in only one bed in the stratigraphic sequence at the study site. Pollen and leaf fossils provide ample regional evidence of the existence of Miocene forests in the hills bordering Chalk Hills Lake [4,5]. Hypotheses 1 and 2 involve different assumptions regarding the processes that transported wood into the ancient lake. They also require different diagenetic conditions that resulted in fossilization. 


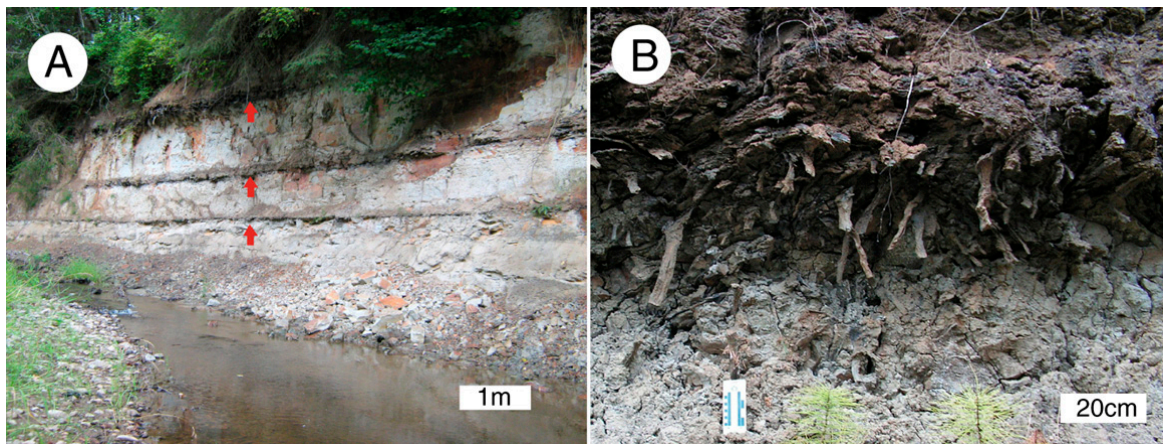

Figure 14. Distal lacustrine lahar deposits in the Miocene Wilkes formation in southeast Washington, USA [34]. (A) Streambank exposure reveals three successive wood mats (arrows); (B) These lahar deposits contain rough-surfaced fragments of mummified wood in a wide range of sizes. Each wood mat is preserved at the top of a fining-upward cycle.

\section{Hypothesis 1. "ordinary deposition"}

This model assumes that wood was gradually released from watershed forests, transported into the lake by normal streamflow, and deposited in the lake over a long period of time. Wood is considered to have been continually introduced into Chalk Hills Lake, rather than by a unique high-energy sedimentary event. Fossilization of wood in the Bruneau Woodpile stratum is considered to be the result of unique geochemical conditions; at other stratigraphic levels wood originally incorporated in the sediments was destroyed during diagenesis.

The natural buoyancy of wood causes it to float until cellular spaces become water saturated, resulting in a slow settling rate. Similarly, pumice settles only after vesicles become waterlogged, which is a slow process for large clasts. Experimental evidence reveals that 4-20 mm diameter pumice clasts require $50-100 \mathrm{~h}$ of water exposure to become saturated [35]. The wood-bearing layer contains pumice clasts up to $7 \mathrm{~cm}$ in diameter, a size that indicates these porous clasts experienced prolonged moisture contact prior to their transport into the lake. At the Bruneau Woodpile site, fossil wood occurs only in a single stratum, the lowest bed of a fining-upward sedimentary cycle, where rhyolitic volcaniclastic material is the dominant constituent.

Although hypothesis 1 is described herein as "ordinary deposition", a complex sequence of processes is required to explain the origin of the Bruneau Woodpile bed. The presence of wood and large pumice clasts in the basal bed requires both materials to have been water-saturated prior to final deposition. Hypothesis 1 presumes that wood and pumice were independently deposited on the lake bottom, subsequently intermixed with volcaniclastic sand during an episode of high-energy sediment transport. To complete the genetic sequence, wood in this stratum became phosphatized; conditions necessary for phosphatization did not exist in all of the other stratigraphic levels, consequently the wood decomposed during diagenesis.

\section{Hypothesis 2. "catastrophic deposition"}

A very different model is that the wood-bearing stratum originated by an unusual event, when watershed forests were damaged by a major storm, producing a subaerial reservoir of branches, single limbs and wood fragments that became waterlogged prior to or during transport. This organic debris arrived at the lake concurrently with volcaniclastic sediment, producing a density current. The first materials to settle were coarse clastic grains, waterlogged pumice fragments, and waterlogged woods. Smaller clastic grains settled at a slower rate, producing a fining-upward sequence.

Hypothesis 2 involves a scenario where wood is introduced into Chalk Hills Lake as the result of a catastrophic incident that released large volumes of woody debris. This scenario presumes an event 
that resulted in severe structural damage to forests in the local watershed. One possibility is the onset of botanical disease, akin to the pine bark beetle epidemic currently decimating large forest area in western North America (Figure 15).

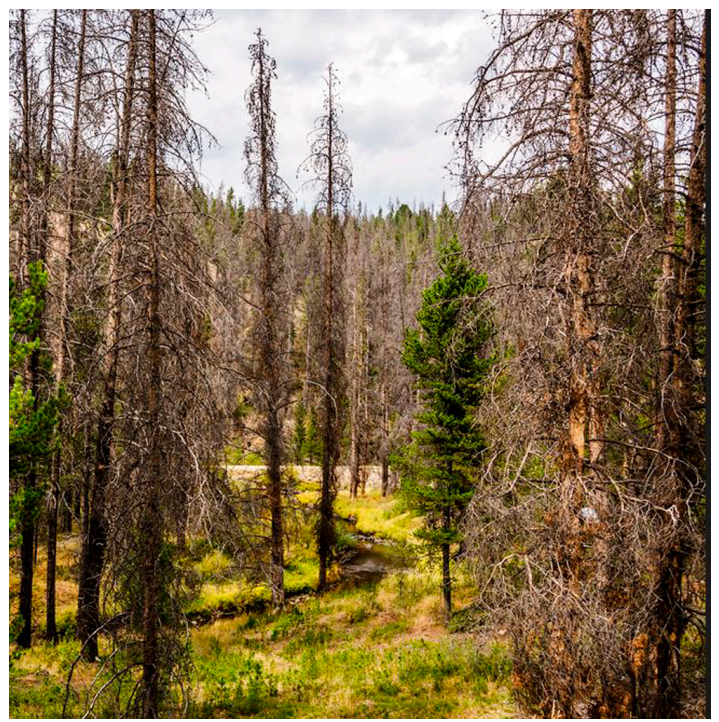

Figure 15. Lodgepole Pine (Pinus contorta) killed by Mountain Pine Beetle (Dendroctonus), Montana, USA. This beetle only attacks certain Pinaceae species [36].

Forest destruction caused by disease or insect infestation is inconsistent with the taxonomic diversity of fossil woods at Bruneau Woodpile; plant pathogens and invading insects are typically specific to a particular host. In addition, tree death does not directly result in stripping of branches, which requires a subsequent storm event. However, some Bruneau Woodpile specimens show evidence of insect and fungal attack (Figure 16); Fossilized bracket fungi have previously been reported [8,25,37]; these fungi are typically found on the trunks of dead or dying trees in modern forests.
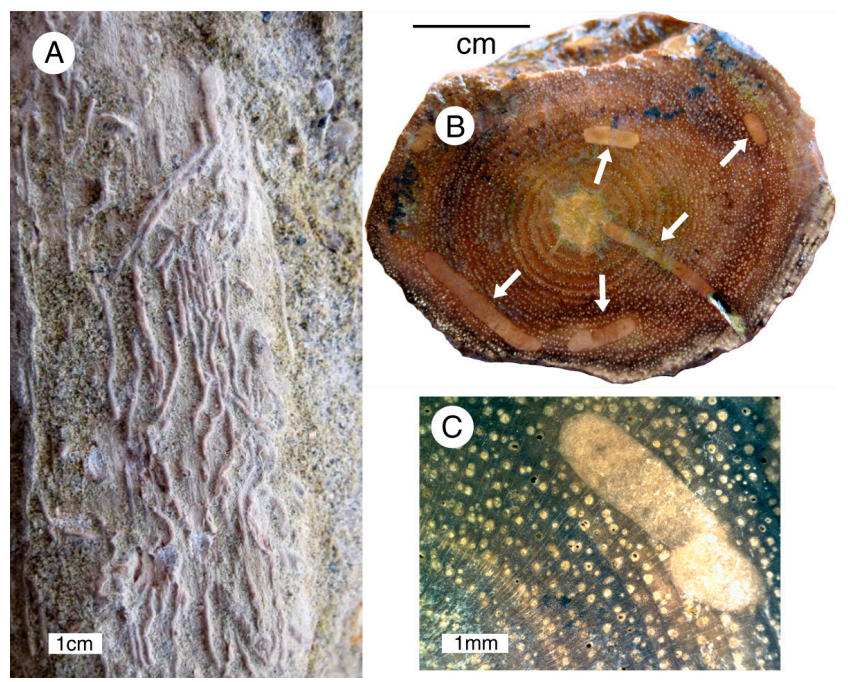

Figure 16. Insect galleries are commonly preserved in specimens from Bruneau Woodpile. (A) Galleries in limb wood just below the bark layer probably made by insect larvae; (B) Galleries penetrating deeply into a hardwood limb; (C) close up view of insect gallery aligned subparallel to annual rings. 
An alternate possibility to a pest epidemic is that trees were damaged by an intense wind storm, similar to the forest destruction caused by wind blast from the 1980 eruption of Mount Saint Helens (WA, USA). During this explosive eruption, air blasts toppled thousands of trees, stripping away limbs to leave a carpet of fallen trunks oriented by the wind direction (Figure 17A,B). In other more protected areas, dead trees were left standing, with many intact branches. Subsequently, the branches and small trunk fragments were removed, swept downslope by the combined effects of wind and rain, leaving behind the parent logs (Figure 17C).

Interpretation of past geologic events can seldom be done with certainty, but the principle of parsimony ("Occam's razor") potentially provides a useful tool. This principle states that among competing hypotheses, the one with the fewest assumptions is preferred [38].

In our study, hypothesis 1 presumes the delivery of wood, pumice, and sandy sediment occurred as independent events, with subsequent reworking of these materials producing a well-defined stratum at the base of a fining-upward sedimentary cycle. If wood was routinely delivered to the lake by streams, this wood underwent decomposition in all beds except for the Bruneau Woodpile stratum, where the tissues instead became petrified. Compare this complex sequence to the relatively simple "catastrophic" scenario of hypothesis 2: A major destructive event damages trees on watershed hill slopes; Wood and pumice clasts become saturated from contact with moist soil or standing water. A subsequent precipitation event causes streams to carry a pulse of water-saturated wood and pumice to the lake to produce a density current. Suspended material settles on the lake floor as a fining upward sediment cycle where wood and pumice are deposited in the basal bed. Fossil wood does not occur in other strata because the transport of woody debris was not an ongoing process. Instead, this transport was preceded by an unusual forest destruction event.

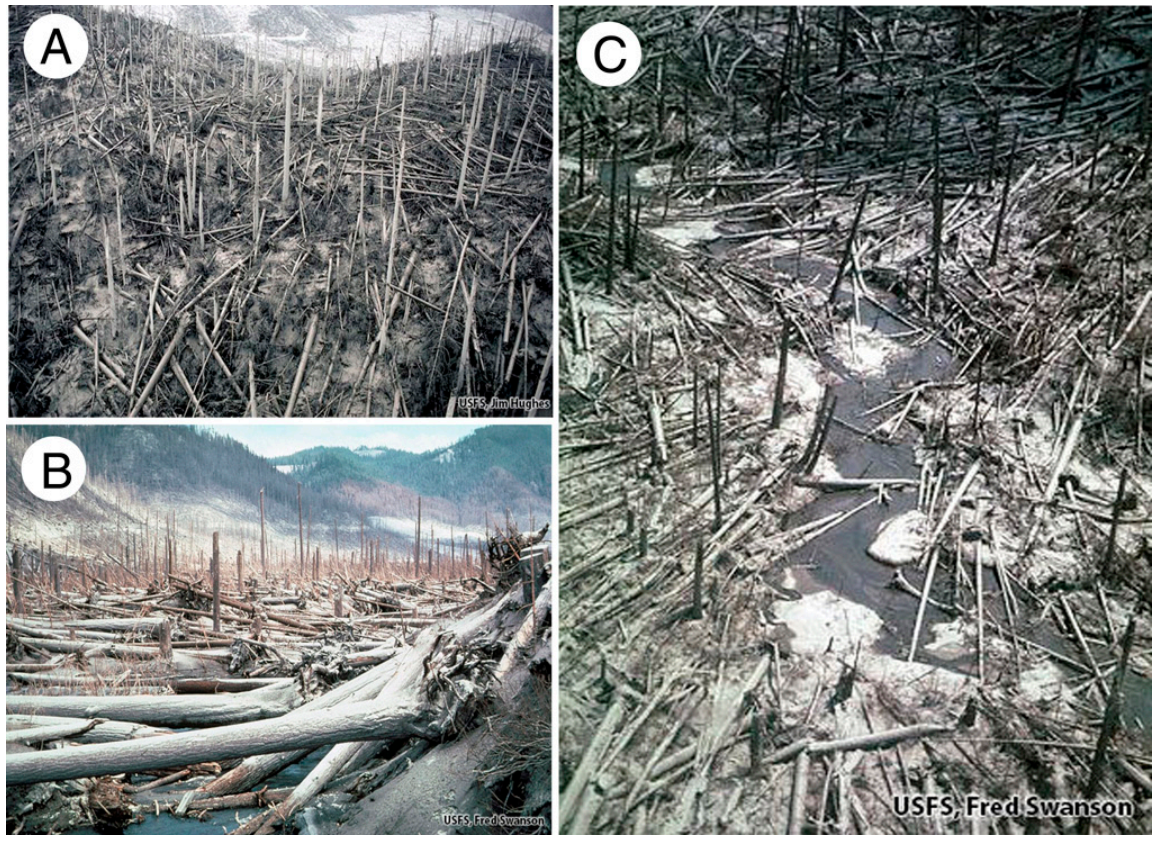

Figure 17. Destruction of trees from May 18, 1980 eruption of Mount Saint Helens (WA, USA). $(\mathbf{A}, \mathbf{B})$ "Blast zone" where fallen logs are oriented in the direction of wind created during explosive eruption. In more protected areas some trees were left standing, and even on fallen trees fractured limbs remained on the ash-covered ground surface; (C) Streams flowing down blast zone slopes transported ash, pumice, and broken limbs, but lacked sufficient energy to move fallen logs. Photos courtesy of United States Forest Service.

"Catastrophic hypothesis 2" is consistent with the Neogene geologic history of the Snake River Plain. In late Miocene time, a series of rhyolite volcanic eruptions produced periodic influxes of 
rhyolitic volcaniclastic debris and tephra. In this geologic setting, the distinction between "ordinary"” and "catastrophic" processes is blurred; from the perspective of geologic time, "rare" events may become relatively common. The sequence of late Miocene events that produced the unusual Bruneau Woodpile petrified wood occurrence cannot be reconstructed with certainty, but the principle of parsimony favors hypothesis 2. A simplified depiction of this scenario is shown in Figure 18.

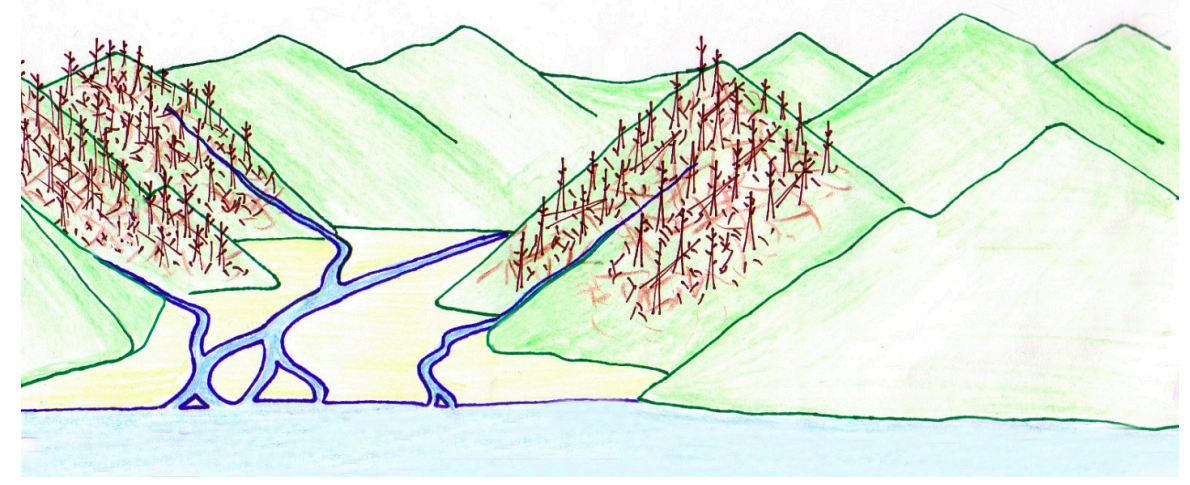

Figure 18. This reconstruction illustrates streams carrying woody debris and sediment to Chalk Hills Lake in the late Miocene. Original artwork by Jessie Thorenson.

\subsection{Mineralogy and Geochemistry}

The first detailed description of francolite (fluorapatite) was provided by Sandell et al. [39], though the mineral name was used as early as 1850. Apatite has previously been reported as a common mineral in phosphatic sediments and fossils [40].

Studies of lacustrine phosphatic oolite in the Pliocene Glenns Ferry Formation, which overlies the Chalk Hills Formation have demonstrated the presence of fluorapatite ("francolite") as an important constituent [41,42]. SEM/EDS analyses show that isolated fish vertebra in the wood-bearing stratum at Bruneau Woodpile are composed of carbonate-fluorapatite.

\subsection{Source of Phosphorus}

Phosphorus has been described as the 10th [43] or 11th [44] most abundant element in the Earth's crust, but under pristine environmental conditions this element is typically present only at low concentration. In the USA., background orthophosphate concentrations from 400 shallow wells were found to average $0.03 \mathrm{mg} / \mathrm{L}$ [45]. Although, in regions affected by anthropogenic contributions: agricultural fertilizer, leaking septic systems, and animal manure, the levels can be higher [46]. In typical terrestrial settings phosphorus is a limiting factor for primary producers. Yet, phosphorus is a macronutrient needed by all living organisms for making membranes, nucleic acids, and ATP-life's energy currency.

Phosphorus enters the food chain through primary producers who obtain their phosphorus from both the residues of organisms and the weathering and erosion of phosphate-containing minerals and rock, most of which owes its origin to ancient shallow marine environments. All consumers obtain their phosphorus by eating other organisms. Thus, food webs allow for the bioaccumulation of phosphorus. Fish obtain their phosphorus from ingesting other organisms; seabirds that consume these fish produce guano that releases the accumulated phosphorus back into the environment. Similarly, bats excrete guano that is phosphorus-rich because of their consumption of insects. The cycling of phosphorus in the natural environment is complex, involving processes where living organisms interact with and depend upon the rock cycle; the phosphorus cycle is a topic that has paleontologic relevance. For example, Arena [47] suggested that some Australian phosphatized wood owed its origin to the close proximity of caves that contained bat guano. 
Both organic and inorganic sources of phosphorus are relatively rare in terrestrial environments making the origin of phosphorus needed for the formation of nonmarime-phosphatized rocks or the mineralization of phosphatized fossils in many localities enigmatic. Likewise, the origin of carbonate-fluorapatite mineralized wood at the Bruneau Woodpile poses a mystery. It is tempting to consider that the Bruneau area may have received phosphorus from regionally extensive bedrock source, the Phosphoria Formation, which contains abundant $\mathrm{Ca}$ and P. These Permian marine rocks are part of a regional stratigraphic sequence known as the Western Phosphate Field. The Phosphoria Formation, which represents shallow subtidal to intertidal deposition, originating at least in part from intertidal oolitic shoals, has been studied in detail [48-51]. Because present-day surface outcrops of the Phosphoria Formation in Idaho are restricted to the eastern part of the state, it is doubtful this could be the source of phosphorus in the deposits at Bruneau Woodpile. A massive fish kill could also act as a source of phosphorus and while disarticulated fish remains are mixed with fossil wood at the Bruneau Woodpile they are sparse.

\subsection{Mineralization Process}

Phosphatization of wood has received little study, but evidence from other research is useful for understanding the mineralization processes. These occurrences reveal that phosphate mineralization can occur in diverse geologic settings (Table 3).

Mineralogic aspects of phosphatized wood have received little previous attention, but more than one pathway may be involved. This possible variation is reminiscent of wood silicification, which can result from a variety of sequential processes [61,62]. SEM images of examples of apatite-mineralized wood from other North American Cenozoic formations are shown in Figure 19. Briefly previewed here, these phosphatized specimens are from localities that will be described in detail in a future report.

The specimen from the Virgin Valley Formation (NV, USA) (Figure 19A,B) comes from a late Miocene lakebed deposit where opalized fossil wood is abundant; this phosphatized wood presumably represents a highly localized geochemical anomaly. High magnification images show that the apatite crudely preserves anatomical features of cell walls, but the network of relatively large crystals has poor fidelity for fine details. This crystallinity suggests that the organic matter provided a favorable chemical $\mathrm{Eh} / \mathrm{pH}$ environment for inorganic precipitation of $\mathrm{Ca}_{5}\left(\mathrm{PO}_{4}\right)_{3}$, but that molecule-by-molecule organic templating was not involved. An alternate possibility is that original fine-grained apatite was later subject to diagenetic recrystallization.

Phosphatized wood from Santa Fe River (FL, USA) (Figure 19C,D) has been fluvially transported from the original locality, so the geologic origin is enigmatic. Like the Nevada wood, tracheid boundaries and cell surface features are visible, but the coarse crystallinity obscures fine details. In this Florida wood, apatite is commonly present as botryoidal encrustations made up of radiating crystals.

Table 3. Known phosphatized wood occurrences.

\begin{tabular}{cccc}
\hline Location & Age & Setting & Reference \\
\hline Illinois, USA & Jurassic & marine & {$[52]$} \\
Svalbard, Boreal Realm & Jurassic & marine & {$[53,54]$} \\
Swindon, U.K. & Jurassic & marine & {$[55]$} \\
Antarctica & Cretaceous & continental & {$[56]$} \\
New Mexico, USA & Cretaceous & continental & {$[57]$} \\
California, USA & Eocene & continental & This report \\
Australia & Miocene/Oligocene & continental & {$[47]$} \\
Nevada, USA & Miocene & continental & This report \\
Idaho, USA & Miocene & continental & This report \\
Uganda & Miocene/Pliocene & continental & {$[58]$} \\
Florida, USA & Neogene & continental & This report \\
France & Pliocene/Pleistocene & continental & {$[59]$} \\
Pacific sea floor & Holocene & marine & {$[60]$} \\
\hline
\end{tabular}




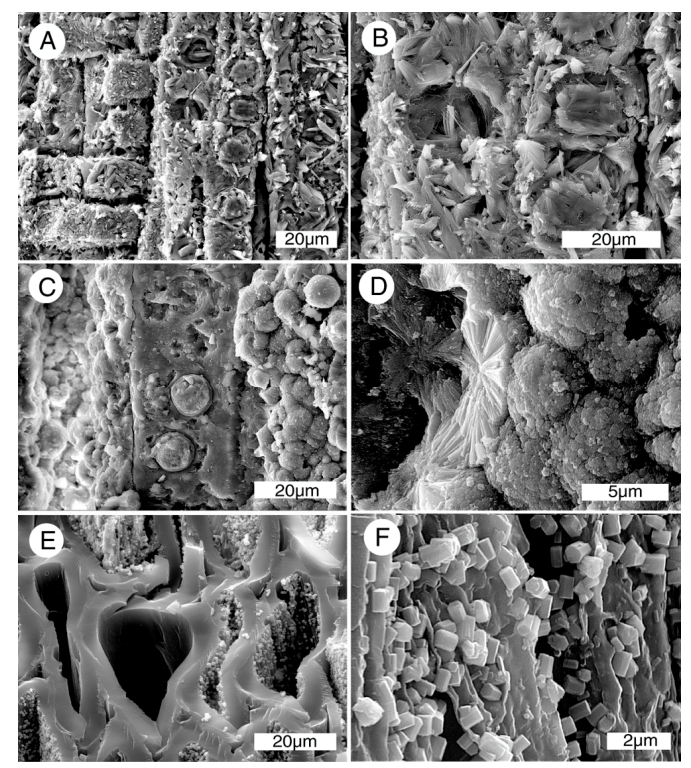

Figure 19. Phosphatized wood from other Cenozoic localities. (A,B) Radial views of Miocene wood from Virgin Valley Formation, northern Nevada, USA, mineralized with fluorapatite; (C,D) Neogene fluorapatite wood from Sante Fe River (FL, USA); (E,F) Apatite crystals on carbonized cell walls, Eocene, Yuba River, Nevada County (CA, USA). Specimens from G. Mustoe research collection, apatite compositions determined by SEM/EDS.

A very different form of apatite occurs in Eocene wood from the Yuba River region in central California (USA) (Figure 19E,F). Samples came from a large carbonized log found in alluvial sediment. Cell walls consist of relict organic matter that has fused into a single homogenous layer. Interior surfaces of these cells contain abundant hexagonal microcrystals. SEM/EDS spectra reveal their composition as pure apatite. The location and morphologies of these crystals are evidence that they originated by inorganic precipitation of $\mathrm{Ca}_{5}\left(\mathrm{PO}_{4}\right)_{3}$ from groundwater that permeated the porous wood long after the cell walls were carbonized. Their origin may have been a result of changes in groundwater chemistry, such as in increase in phosphorus. Alternately, apatite crystallization may have resulted in a change in $\mathrm{Eh} / \mathrm{pH}$ conditions that favored precipitation.

Microbial processes may play a role in phosphatization of faunal remains and phosphatic mineral deposits [63,64], but possible involvement of microbes during phosphatization of wood has not been studied. Previous reports provide abundant evidence for the recognition of microbial associations in aquatic mineral deposits where mineral deposition is facilitated by microbial mats or biofilms. These include spring sinter [65-69] and clastic lake bed sediment [70-72]. An SEM image of one Bruneau Woodpile fossil wood specimen exhibits etching on its surface; these traces are inferred to have been made by a phosphorus-seeking endolith after the wood had already been petrified (Figure 12D). Other fossil wood specimens in this study show no evidence of microbes.

Degradation of relict organic matter may have been important for controlling the Eh and $\mathrm{pH}$ conditions that favored phosphate precipitation. Phosphatization of organic matter under geologic conditions has primarily been studied in deposits that contain fossilized invertebrates, particularly in occurrences were soft tissues are preserved $[40,73-76]$. These fossils typically were preserved in marine sedimentary environments, likely explained by the greater abundance of phosphorus in ocean water and sea floor sediment, compared to the low concentrations typical of terrestrial environments. Furthermore, animal decay also adds a source of phosphate ions. Rapid burial, a reducing environment and anaerobic decay are identified as necessary parameters for phosphatization of animal soft tissue. Once these conditions have been met evidence suggests that a steep chemical gradient resulting in a $\mathrm{pH}$ drop triggers the calcium carbonate—calcium phosphate switch, favoring apatite precipitation [74]. 
Plant tissues are less likely to be phosphatized because they are relatively phosphorus deficient [40]; however, numerous occurrences have been reported and the chemical conditions necessary for their formation may have important parallels to phosphatization of marine organisms.

One detailed experimental study [77] involved shrimp carcasses that were incubated in a marine medium under aerobic conditions, introducing sulfate-reducing, sulfide-oxidizing and fermentative bacteria. Levels of introduced sulfate, glucose, microbes and sediment were varied among individual samples, as was buffering capacity of the culture medium. In most experiments, oxygen was quickly depleted, $\mathrm{pH}$ decreased, and sulfate accumulated. The result was anaerobic decay, accompanied by steep chemical gradients near the shrimp carcasses. In areas where decay was intense, $\mathrm{pH}$ decreased markedly, and some muscle tissue was replaced by $\mathrm{Ca}_{5}\left(\mathrm{PO}_{4}\right)_{3}$. In less decayed areas, $\mathrm{CaCO}_{3}$ crystals precipitated. Local $\mathrm{pH}$ appeared to be the most important factor for determining whether $\mathrm{CaCO}_{3}$ or $\mathrm{Ca}_{5}\left(\mathrm{PO}_{4}\right)_{3}$ was deposited.

These experimental results resemble observations of phosphatization of organic matter under natural conditions. Phosphate-mineralized wood from the Pacific sea floor [60] appears to have resulted from decomposition of organic matter that resulted in decreases in Eh and $\mathrm{pH}$. Because Eh and $\mathrm{pH}$ conditions that control solubility of $\mathrm{CaCO}_{3}$ and $\mathrm{Ca}_{5}\left(\mathrm{PO}_{4}\right)_{3}$ are similar, high phosphorus concentration in the water apparently favored apatite deposition. $\mathrm{Ca}_{5}\left(\mathrm{PO}_{4}\right)_{3}$ was deposited when $\mathrm{pH}$ values were around 6.2. At higher $\mathrm{pH}$, mineralization was dominated by $\mathrm{CaCO}_{3}[60]$.

At the Bruneau Woodpile, all fossil wood is mineralized with carbonate-fluorapatite, but phosphate minerals are not detectable in the surrounding sandstone matrix. This mode of occurrence is evidence that unique geochemical conditions were present within the buried plant tissue. The hyaloclastic lake sediment would have potentially provided an abundant source of dissolved silica: pumice and volcanic ash are commonly associated with silicified wood, and experimental studies have shown obsidian to be a good source of dissolved silica for wood mineralization [78]. The presence of diatom fossils in the lakebed sediment is evidence that dissolved silica was available, and mineralization of the wood with calcium phosphate rather than silica is probable evidence that that $\mathrm{Eh} / \mathrm{pH}$ conditions within the buried tissue were not favorable for silica precipitation. This is consistent with experimental evidence [78] demonstrating that when obsidian powder is used as a silica source, dissolved $\mathrm{Si}$ levels were elevated at $\mathrm{pH}$ values $>9$. For wood that contained absorbed silica, a decrease in $\mathrm{pH}$ caused breakdown of hydrogen bonds between silica complexes and organic molecules, releasing silica back into aqueous solution. These experiments suggest that the low $\mathrm{pH}$ values typical of calcium phosphate precipitation would not have been favorable for silicification. The absence of phosphate minerals in the matrix that encloses the fossil wood is an indication that phospatization involved local geochemical gradients rather than more general diagenetic conditions.

The mode of phosphate mineralization is unclear. One possibility is that at the Bruneau Woodpile carbonate-fluorapatite was deposited via process of organic templating, where deposition of calcium phosphate was facilitated by an affinity with cell wall constituents, analogous to the hydrogen bonds that form between silica and hydroxyl functional groups on organic wood molecules [56,79]. This organic templating possibility is consistent with SEM views of Bruneau wood, which show that cell walls contain microcrystalline carbonate-fluorapatite that preserves anatomical details with many vessel lumen remaining unmineralized (Figure 11).

\subsection{Paleoclimate}

The Cenozoic climate followed a general cooling trend largely attributable to changes in ocean circulation patterns, but factors such as volcanic emissions and seabed methane releases also played roles. The Paleocene-Eocene Thermal Maximum (PETM) and Pleistocene glacial advances and retreats are notable examples of Cenozoic climatic fluctuations (Figure 20). 


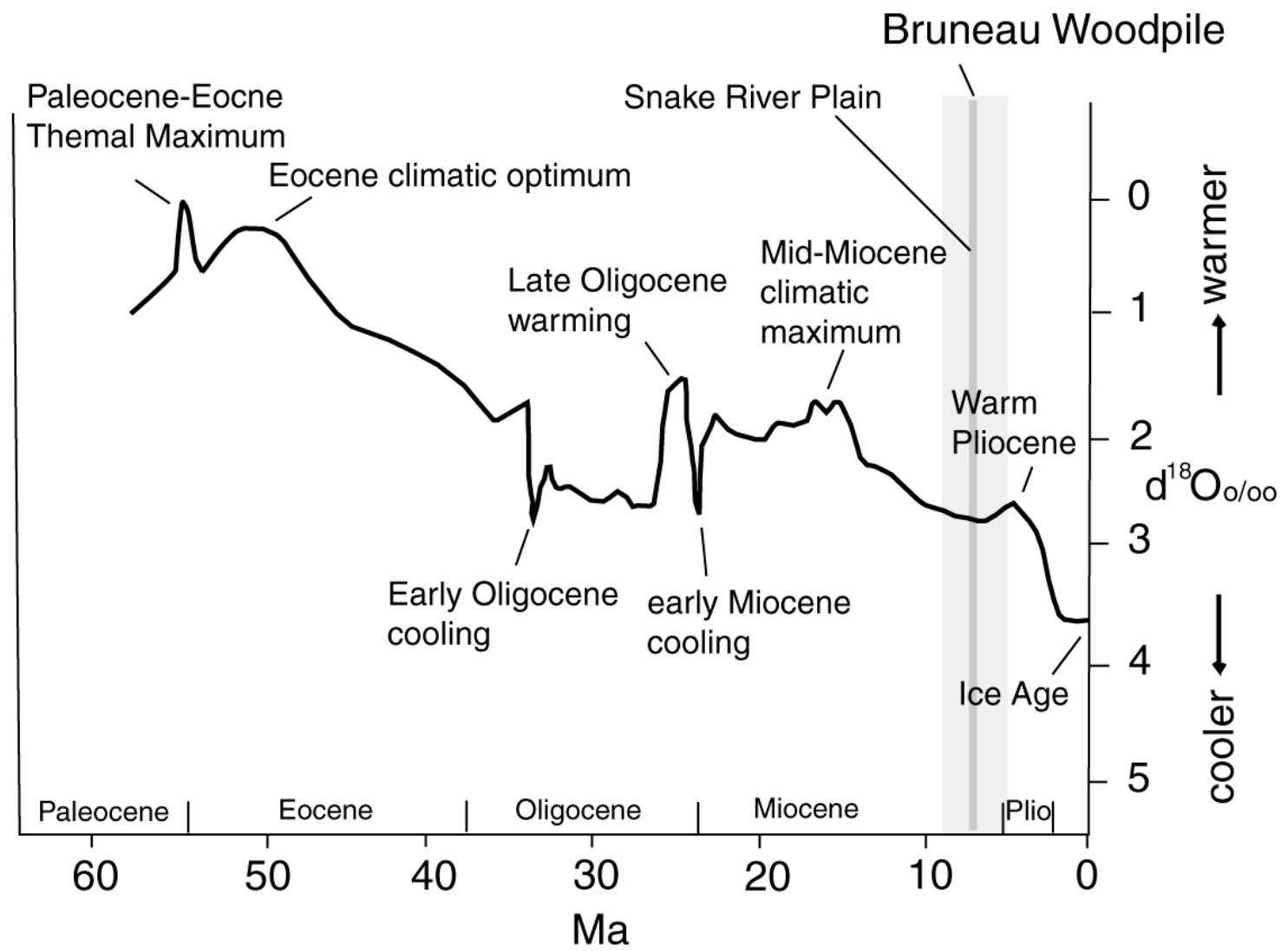

Figure 20. Cenozoic average global temperatures based on oxygen isotope values in marine sediments. Adapted from [80].

Neogene paleoclimatic conditions in southern Idaho have been studied using paleontologic evidence. Plant fossils provide information about regional climatic trends, and fish fossils can be used to study seasonality.

The taxonomic composition of extant taxa found within a fossil assemblage can be compared to modern taxon-climate calibrated floras to infer past climate. In the Pacific Northwest, fossil floras record climatic changes that resulted from the uplift of the Cascade Range in the late Miocene and early Pliocene [5].

Middle to late Miocene-aged fossil floras between latitudes $41^{\circ} \mathrm{N}$ and $46^{\circ} \mathrm{N}$ in the states of Washington and Idaho are composed of broadleaved hardwoods and conifers with some assemblages including swamp elements such as Taxodium-type vegetation. These palaeofloras have strong affinities to modern deciduous forests of eastern and southeastern North America as well as eastern Asia. These modern analogs suggest that a summer-wet climate existed in the Snake River Plain during the middle to late Miocene, with annual precipitation of $>1000 \mathrm{~mm}$, and warm winters, and an estimated mean annual temperature (MAT) of $12-13^{\circ} \mathrm{C}$.

Deposition of the late Miocene Chalk Hills Formation, the host sediment for the Bruneau Woodpile, occurred near the end of this climatic period and the fossil floras of this period indicate a transition towards a more summer-dry climate regime. Primary evidence for this comes from the Pickett Creek flora, which is in the lower Chalk Hills Formation and has been dated at approximately 8.5-10.5 Ma based on geochemical correlation of volcanic ash layers present in the deposit [6]. The Pickett Creek flora lacks many of the exotic taxa that require high humidity and summer rainfall found in older middle Miocene floras of the Latah, Sucker Creek, and Mascall Formations, with increasing dominance of more drought tolerant types such as pines, white oaks, live oaks, and Robinia. The Bruneau Woodpile is thought to be slightly younger than Pickett Creek and the wood types found at Bruneau Woodpile 
closely mirror the Pickett Creek assemblage. Even though the growth of the Cascade Range had not yet created a significant rain shadow, there is evidence to suggest that the climate of the northwest interior was becoming more arid towards the late Miocene [81].

Pliocene-aged fossil floras in the Snake River Plain indicate a continued transition to a more arid climate, resulting from the rain shadow created by the newly-uplifted Cascade Range. These younger paleofloras show the decline of hardwoods, and the appearance of abundant grasses and dryland shrubs, particularly Artemisia (sagebrush). By the early Pleistocene, the transition to modern sagebrush/bunchgrass steppe flora was well under way [5].

Miocene and Pliocene fish faunas that populated Lake Idaho and its Miocene predecessors can be used as proxy sources for climatic parameters based upon their distributions and the limiting temperature for nearest living relatives. During the late Miocene, the cold month mean temperature is estimated to be $10^{\circ} \mathrm{C}$, compared to $0{ }^{\circ} \mathrm{C}$ for the Pliocene, and a reduction in the number of frost-free days $\left(<0{ }^{\circ} \mathrm{C}\right)$ from 270 to 175 . The seasonal range or difference between the mean for coldest and warmest month increased from $11^{\circ} \mathrm{C}$ during the late Miocene to $21{ }^{\circ} \mathrm{C}$ during the Pliocene [20].

In summary, evidence from previous studies of fossil leaf, pollen and fish fossils suggests that the trees that produced the Bruneau Woodpile came from forests that existed during the climatic transition that occurred near the close of the Miocene Epoch. This plant community represents an assemblage that contains more summer-dry adapted taxa than the earlier mid-Miocene floras of the region; very different from the arid conditions that exist today.

\section{Conclusions}

The Bruneau Woodpile is an unusual deposit, providing a rare opportunity to collect abundant specimens of fossil wood mineralized with carbonate-fluorapatite. The taxonomic diversity of the specimens provides a glimpse of an ancient forest growing in a region that was on the brink of climatic change. The region would soon transition from warm temperate to semi-arid. One long-standing enigma of this locality is the abundance of wood in the form of small limbs and trunk fragments, with no larger specimens. The driftwood-like morphology of the specimens is evidence of fluvial transport. As described above, two possible hypotheses are considered. Hypothesis 1 assumes that the wood-bearing stratum resulted from a sequence of ordinary processes, where wood was continuously introduced to the lake, but only preserved in a single stratum, where it was intermixed with waterlogged pumice and volcaniclastic sediment. Hypothesis 2 invokes a catastrophic event that severely damaged local forest, producing a reservoir of branches and wood fragments that gradually became water saturated from soil moisture or in shallow ponds. This material was later transported to the lake during a storm event when a high-energy stream flow simultaneous carried pumice, sand, and silt. This suspended sediment entered Chalk Hills Lake as a turbidity current, the source of the fining-upward sediment cycle that contains wood in the coarse basal bed. The principle of parsimony favors hypothesis 2.

Chemical conditions in the deposit caused mineralization of the wood by replacement with carbonate fluorapatite. While the exact mechanism could not be determined, the process may have been similar to the silicification of wood in which the wood acts as a template for the mineralization process. Microbes do not appear to have been directly responsible for phosphatization, but inorganic phosphate precipitation may have been the result of $\mathrm{Eh} / \mathrm{pH}$ gradients that were strongly influenced by the decomposition of relict organic matter.

Supplementary Materials: The following are available online at www.mdpi.com/2076-3263/7/3/82/s1. Atlas of wood types from the Bruneau Woodpile, with transverse section images and anatomical descriptions.

Acknowledgments: Rick Dillhoff and Mary Klass assisted with excavation and specimen collecting. Elisabeth Wheeler provided helpful advice for interpreting photomicrographs. Nancy and Larry Dillon provided guidance in how to work the fossil site and provided some samples Richard Rantz contributed specimens collected in 1997 for initial chemical analyses. Yuba River, California USA specimens (Figure 19) provided by David Lawler, Farwest Geoscience Foundation Director. Jessie Thoreson provided the (Figure 18) sketch. We thank Barbara Nash for determining the age of the ash. 
Author Contributions: The investigation was conceived and directed by Viney. Link provided stratigraphic data and age determinations. Link, Viney, Dillhoff participated in field work; taxonomic identifications were provided by Dillhoff. Mustoe provided graphic art., photomicrographs, SEM/EDS data, XRD and XRF analyses. The manuscript was written by Mustoe and Viney, with contributions from the other coauthors.

Conflicts of Interest: The authors declare no conflicts of interest.

\section{References}

1. Lewis, R.S.; Link, P.K.; Stanford, L.R.; Long, S.P. Geological Map of Idaho; Idaho Geological Survey Map 9; scale 1:750,000; Idaho Geological Survey: Moscow, ID, USA, 2012.

2. Kimmel, P.G. Stratigraphy, age, and tectonic setting of the Miocene-Pliocene lacustrine sediments of the western Snake River Plain, Oregon and Idaho. In Cenozoic Geology of Idaho; Bonnichsen, B., Breckenridge, R.M., Eds.; Idaho Bureau of Mines and Geology Bulletin: Moscow, ID, USA, 1982; Volume 26, pp. 559-578.

3. Leopold, E.B.; Wright, V.C. Pollen profiles of the Plio-Pleistocene transition in the Snake River Plain, Idaho. In Late Cenozoic History of the Pacific Northwest; Smiley, C.J., Ed.; Pacific Division, American Association for the Advancement of Science: Washington, DC, USA, 1985; pp. 323-348.

4. Leopold, E.B.; Denton, M.F. Comparative age of grassland and steppe east and west of the northern Rocky Mountains. Ann. Mo. Bot. Gard. 1987, 74, 841-867. [CrossRef]

5. Mustoe, G.E.; Leopold, E.B. Paleobotanical evidence for the post-Miocene uplift of the Cascade Range. Can. J. Earth Sci. 2014, 51, 809-824. [CrossRef]

6. Buechler, W.K.; Dunn, M.T.; Rember, W.C. Late Miocene Pickett Creek flora of Owyhee County, Idaho. Univ. Mich. Contrib. Mus. Paleontol. 2007, 31, 305-362.

7. Root, J.V. Bruneau wood. Gems Miner. 1971, 409, 36-37.

8. Brown, R.W. A bracket fungus from the late Tertiary of southwestern Idaho. J. Wash. Acad. Sci. 1940, 30, 422-424.

9. Axelrod, D.I. Cenozoic History of Some Western American Pines. Ann. Mo. Bot. Gard. 1986, 73, 565-641. [CrossRef]

10. Pierce, K.L.; Morgan, L.A. The track of the Yellowstone hot spot: Volcanism, faulting, and uplift. In Regional Geology of Eastern Idaho and Western Wyoming; Link, P.K., Kuntz, M.A., Platt, L.B., Eds.; Geological Society of America Memoir: Boulder, CO, USA, 1992; Volume 179, pp. 1-53.

11. Rodgers, D.W.; Ore, H.T.; Bobo, R.T.; McQuarrie, N.; Zentner, N. Extension and subsidence of the eastern Snake River Plain, Idaho. In Tectonic and Magmatic Evolution of the Snake River Plain Volcanic Province; Idaho Geological Survey Bulletin 30; Bonnichsen, B., White, C.M., McCurry, M., Eds.; Idaho Geological Survey: Moscow, ID, USA, 2002; pp. 121-155.

12. Shervais, J.W.; Kauffman, J.D.; Gillerman, V.S.; Othberg, K.L.; Vetter, S.K.; Hobson, V.R.; Zarnetske, M.; Cooke, M.F.; Matthews, S.H.; Hanan, B.B. Basaltic volcanism of the central and western Snake River Plain: A guide to field relations between Twin Falls and Mountain Home, Idaho. In Interior Western United States: Geological Society of America Field Guide 6; Pederson, J., Dehler, C.M., Eds.; Geological Society of America: Boulder, CO, USA, 2005; Volume 6, pp. 27-52.

13. Bonnichsen, B.; Godchaux, M.M. Late Miocene, Pliocene, and Pleistocene geology of southwestern Idaho with emphasis on basalts in the Bruneau-Jarbidge, Twin Falls and Western Snake River Plain regions. In Tectonic and Magmatic Evolution of the Snake River Plain Volcanic Province; Bonnichsen, B., White, C.M., McCurry, M., Eds.; Idaho Geological Survey Bulletin 30; Idaho Geological Survey: Moscow, UD, USA, 2002; pp. 233-312.

14. Malde, H.E. Stratigraphy of the Glenns Ferry from Hammett to Hagerman, Idaho; U.S. Geological Survey Bulletin 1331-D; United States Government Printing Office: Washington, DC, USA, 1972; 19p.

15. Hagerman Fossil Beds National Monument, Idaho. Available online: http://www.nps.gov/hafo/ (accessed on 30 April 2017).

16. Wood, S.H.; Clemens, D.M. Geologic and tectonic history of the western Snake River Plain, Idaho and Oregon. In Tectonic and Magmatic Evolution of the Snake River Plain Volcanic Province; Bonnichsen, B., White, C.M., McCurry, M., Eds.; Idaho Geological Survey Bulletin 30; Idaho Geological Survey: Moscow, ID, USA, 2002; pp. 69-103. 
17. Jenks, M.D.; Bonnichsen, B.; Godchaux, M.M. Geologic Map of the Grand-View Bruneau Area, Owyhee County, Idaho; Digitally Revised Version, Idaho Geological Survey Technical Report 98-1; Idaho Geological Survey: Moscow, ID, USA, 1998.

18. Malde, H.E.; Powers, H.A. Geologic Map of the Glenns Ferry-Hagerman Area, West-Central Snake River Plane Idaho; scale 1:48,000; Map I-696; U.S. Geological Survey Miscellaneous Investigations; U.S. Geological Survey: Reston, VA, USA, 1972.

19. Smith, G.R.; Swirydczuk, K.; Kimmel, P.G.; Wilkinson, B.H. Fish biostratigraphy of the late Miocene to Pleistocene sediments of the western Snake River Plain, Idaho. In Cenozoic Geology of Idaho; Bonnichsen, B., Breckenridge, R.M., Eds.; Idaho Bureau of Mines Geology Bulletin: Moscow, ID, USA, 1982; Volume 26, pp. 519-542.

20. Smith, G.R.; Patterson, W.P. Mio-Pliocene seasonality on the Snake River plain: Comparison of faunal and oxygen isotopic evidence. Palaeogeogr. Palaeoclimatol. Palaeoecol. 1994, 107, 291-302. [CrossRef]

21. Ruez, D.R., Jr. Middle Pliocene paleoclimate in the Glenns Ferry Formation of Hagerman Fossil Beds National Monument, Idaho: A baseline for evaluating faunal change. J. Ida. Acad. Sci. 2006, 42, 1-16.

22. Perkins, M.E.; Brown, F.H.; Nash, W.P.; McIntosh, W.; Williams, S.K. Sequence, Age, and Source of Silicic Fallout Tuffs in Middle to Late Miocene Basins of the Northern Basin and Range Province; Geological Society of America Bulletin: Boulder, CO, USA, 1998; Volume 110, pp. 344-360.

23. Panshin, A.J.; DeZeeuw, C. Textbook of Wood Technology, 3rd ed.; McGraw-Hill: New York, NY, USA, 1970; 705p.

24. Wheeler, E.A. InsideWood-A web resource for hardwood anatomy. IAWA J. 2011, 32, 199-211.

25. Kirkby, R. Bounty of Bruneau-Fossil treasures in southern Idaho. Gems Miner 1998, 28, 52-55.

26. Nash, B.; University of Utah, Salt Lake City, UT, USA. Personal communication, 2015.

27. Morgan, L.A.; McIntosh, W.C. Timing and Development of the Heise Volcanic Field, Snake River Plain, Idaho, Western USA; Geological Society of America Bulletin: Boulder, CO, USA, 2005; Volume 117, pp. 288-306. [CrossRef]

28. Anders, M.H.; Saltzman, J.; Hemming, S.R. Neogene Tephra Correlations in Eastern Idaho and Wyoming Yellowstone for Hotspot-Related Volcanism and Tectonic Activity; Geological Society of America Bulletin: Boulder, CO, USA, 2009; Volume 121, pp. 837-856.

29. Cohen, K.M.; Finney, S.C.; Gibbard, P.L.; Fan, J.-X. The ICS International Chronostratigraphic Chart. Episodes 2013, 36, 199.

30. Elliot, J.C. Structure and Chemistry of the Apatites and Other Orthophosphates. Studies in Inorganic Chemistry 18; Elsevier: New York, NY, USA, 1994; 371p.

31. Hughes, J.M.; Rakovan, J. The crystal structure of apatite $\mathrm{Ca}_{5}\left(\mathrm{PO}_{4}\right)_{3}(\mathrm{~F}, \mathrm{OH}, \mathrm{Cl})$. In Reviews in Mineralogy and Geochemistry; Kohn, M.J., Rakovan, J., Hughes, J.M., Eds.; Mineralogical Society of America: Washington, DC, USA, 2002; Volume 48, pp. 1-12.

32. Godinot, C.; Tribolet, A.; Grover, R.; Ferrier-Pagès, C. Bioerosion by euendoliths decreases in phosphate-enriched skeletons of living corals. Biogeosciences 2012, 9, 2377-2384. [CrossRef]

33. Golubic, S.; Friedmann, I.; Schneider, J. The lithobiontic ecological niche, with special reference to microorganisms. J. Sediment. Res. 1981, 5, 475-478.

34. Yancey, T.M.; Mustoe, G.E.; Leopold, E.B.; Heizler, M.T. Mudflow disturbance in latest Miocene forests in Lewis County, Washington. PALAIOS 2013, 28, 343-358. [CrossRef]

35. White, J.D.; Manville, V.; Wilson, C.J.N.; Houghon, B.F.; Riggs, N.R.; Ort, M. Settling and deposition of AD 181 Taupo pumice in lacustrine and associated environments. In Volcaniclastic Sedimentation in Lacustrine Settings; White, J.D.L., Riggs, N.R., Eds.; Blackwell Publishing Ltd.: Oxford, UK, 1999; pp. 141-150.

36. Furniss, R.L.; Carolin, V.M. Western Forest Insects; U.S. Department of Agriculture, Forest Service, Miscellaneous Publication: Washington, DC, USA, 1977; No. 1339; 346p.

37. Andrews, H.N.; Lenz, L.W. Fossil polypores from Idaho. Ann. Mo. Bot. Gard. 1947, 34, 113-114. [CrossRef]

38. Gauch, H.G. Scientific Method in Practice; Cambridge University Press: Cambridge, UK, 2003; ISBN 0-521-01708-4.

39. Sandell, E.B.; Hay, M.H.; McConnell, D. The composition of francolite. Mineral. Mag. 1939, 25, $395-401$. [CrossRef]

40. Lucas, J.; Prévôt, L.E. Phosphates and fossil preservation. In Taphonomy: Releasing the Data Locked in the Fossil Record; Allison, P.A., Briggs, D.E.G., Eds.; Plenum Press: New York, NY, USA, 1991; pp. 389-409. 
41. Swirydczuk, K.; Wilkinson, B.H.; Smith, G.R. The Pliocene Glenns Ferry oolite: Lake-margin carbonate deposition in the southwestern Snake River plain. J. Sediment. Res. 1979, 49, 114-1129.

42. Swirydczuk, K.; Wilkinson, B.H.; Smith, G.T. Synsedimentary lacustrine phosphorites from the Pliocene Glenns Ferry Formation of southwestern Idaho. J. Sediment. Res. 1981, 51, 1205-1214.

43. Wedepohl, K.H. The composition of the continental crust. Geochim. Cosmochim. Acta 1995, 59, 1217-1232. [CrossRef]

44. Fleischer, M. Recent Estimates of the Abundances of Elements in the Earth's Crust; U.S. Geological Survey Circular 285; USGS: Reston, VA, USA, 1953; pp. 1-3.

45. Dubrowsky, N.M.; Burrow, K.R.; Clark, G.M.; Gronberg, J.M.; Hamilton, P.A.; Hitt, K.J.; Mueller, D.K.; Munn, M.D.; Nolan, B.T.; Puckett, L.J.; et al. The quality of our Nation's waters-Nutrients in the Nation's streams and groundwater, 1992-2004; U.S. Geological Survey Circular 1350; USGS: Reston, VA, USA, 2010; 174p.

46. Dunne, T.; Leopold, L.B. Water in Environmental Planning, 1st ed.; W.H. Freeman: New York, NY, USA, 1978.

47. Arena, D.A. Exceptional preservation of plants and invertebrates by phosphatization, Riversleigh, Australia. PALAIOS 2008, 23, 495-502. [CrossRef]

48. Sheldon, R.P.; Warner, M.A.; Thompson, M.E.; Pierce, H.W. Stratigraphic Sections of the Phosphoria Formation in Idaho, 1949. Part 1; U.S. Geological Survey Circular 304; USGS: Reston, VA, USA, 1949.

49. McKelvey, V.E.; Armstrong, R.A.; Gulbrandsen, R.A.; Campbell, R.M. Stratigraphic sections of the Phosphoria Formation in Idaho, 1947-48, Part 2; Geological Survey Information Circular 301; USGS: Reston, VA, USA, 1953.

50. Petrun, R.M. Field guide to the southeast Idaho phosphate district. In Guidebook to the Geology of Eastern Idaho; Hughes, S.S., Thackray, G.D., Eds.; Idaho Museum of Natural History: Moscow, ID, USA, 1999; pp. 269-280.

51. Piper, D.Z.; Link, P.K. An Upwelling Model for the Phosphoria Sea: A Permian, Ocean-Margin Sea in the Northwest United States. Am. Assoc. Petroleum Geol. Bull. 2002, 86, 1217-1235.

52. Gluskoter, H.J.; Pierard, L.H.; Pfefferkorn, H.W. Apatite petrifacations in Pennsylvanian shales of Illinois. J. Sediment. Res. 1970, 40, 1363-1366. [CrossRef]

53. Krajewski, K.P. Organic geochemistry of a phophorite to black shale transgressive succession: Wilhelmøya and Janusfjellet Formations (Rhætian-Jurassic) in Central Spitsbergen, Arctic Ocean. Chem. Geol. 1989, 11, 331-334.

54. Reolid, M.; Philippe, M.; Nagy, J.; Abad, I. Preservation of phosphatic wood remains in marine deposits of the Brentskardhaugen Bed (Middle Jurassic) from Svalbard (Boreal Realm). Facies 2010, 56, 549-566. [CrossRef]

55. Scott, A.C.; Collinson, M.E. Non-destructive multiple approaches to interpret the preservation of plant fosils: Implications for calcium-rich permineralizations. J. Geol. Soc. 2003, 160, 857-862. [CrossRef]

56. Jefferson, T.H. The preservation of conifer wood: Examples from the Lower Cretaceous of Antarctica. Paleontology 1987, 30, 232-249.

57. Sweeney, I.J.; Chin, K.; Hower, J.C.; Budd, D.A.; Wolfe, D.G. Fossil wood from the middle Cretaceous Moreno Hill Formation: unique expressions of wood mineralization and implications for the process of wood preservation. Int. J. Coal Geol. 2009, 79, 1-17. [CrossRef]

58. Pailler, D.; Flicoteaux, R.; Ambrosi, J.P.; Médus, J. Les bois fossils mio-pliocènes de Nkondo (Lac Albert, Ouganda), composition minéralogique et mode de formation. C R Acad. Sci. Paris Sci. Terre et Planets 2000, 331, 279-286.

59. Koeniguer, J.C. Sur une liane plio-quaternaire du Tchad. Bulletin du Muséum National d'Histoire Naturelle, Sciences de la Terre 1973, 172, 81-91.

60. Goldberg, E.D.; Parker, R.H. Phosphatized wood from the Pacific sea floor. Bull. Geol. Soc. Am. 1960, 71, 631-632. [CrossRef]

61. Mustoe, G.E. Late Tertiary petrified wood from Nevada, USA: Evidence of multiple silicification pathways. Geosciences 2015, 5, 286-309. [CrossRef]

62. Viney, M.; Dietrich, D.; Mustoe, G.; Link, P.; Lampke, T.; Götze, J.; Rößler, R. Multi-stage silicification of Pliocene wood: Re-examination of an 1895 Discovery from Idaho, USA. Geosciences 2016, 6, 21. [CrossRef]

63. Crosby, C.H.; Bailey, J. The role of microbes in the formation of modern and ancient phosphatic mineral deposits. Front. Microbiol. 2012, 3, 241-247. [CrossRef] [PubMed]

64. Omelon, S.; Ariganello, M.; Bonucci, E.; Grynpas, M.; Nanci, A. A review of phosphate mineral nucleation in biology and geobiology. Calcif. Tissue Int. 2013, 93, 382-396. [CrossRef] [PubMed]

65. Jones, B.; Renaut, R.W.; Rosen, M.R. Biogenicity of silica precipitation around geysers and hot-spring vents, North Island, New Zealans. J. Sediment. Res. 1997, 67, 88-104. 
66. Walter, M.R.; McKloughlin, S.; Drinnan, A.N.; Farmer, J.D. Paleozoic hot spring sinter in the Drumond Basin, Queensland, Australia. Econ. Geol. 1998, 84, 135-143.

67. Konhauser, K.O.; Phoenix, V.R.; Bottrell, S.H.; Adams, D.G.; Head, I.M. Microbial-silica interactions in Icelandic hot spring sinter: Possible analogues for some Precambrian iron stromatolites. Sedimentology 2001, 48, 425-433. [CrossRef]

68. Guidry, S.A.; Chafetz, H.S. Depositional facies and diagentic alteration in a relict siliceous hot-spring accumulation: Examples from Yellowstone National Park, U.S.A. J. Sediment. Res. 2003, 73, 806-823. [CrossRef]

69. Hinman, N.W.; Walter, M.R. Textural preservation in siliceous hot spring deposits during early diagenesis: Examples from Yellowstone National Park and Nevada, U.S.A. J. Sediment. Res. 2005, 75, 200-215. [CrossRef]

70. Knoll, A.H. Exceptional preservation of photosynthetic organisms in silicified carbonates and silicified peats. Philos. Trans. R. Soc. Lond. 1985, B311, 111-122. [CrossRef]

71. Harding, I.C.; Chant, L.S. Self-cemented diatom mats as agents of exceptional fossil preservation in the Oligocene Florissant lake beds, Colorado, United States. Geology 2000, 28, 195-198. [CrossRef]

72. O'Brien, N.R. The Role of Biofilm in Fossil Preservation in the Late Eocene Florissant Forest, Colorado; Geological Society of America Special Paper 435; Geological Society of America: Golden, CO, USA, 2008; pp. $19-31$.

73. Briggs, D.E.K. The role of decay and mineralization in the preservation of soft-bodied fossils. Annu. Rev. Earth Planet. Sci. 2003, 31, 275-301. [CrossRef]

74. Briggs, D.E.H.; Wilby, P.R. The role of the calcium carbonate-calcium phosphate switch in the mineralization of soft-bodied fossils. J. Geol. Soc. Lond. 1996, 153, 665-668. [CrossRef]

75. Briggs, D.E.G.; Kear, A.J.; Maretill, D.M.; Wilby, P.R. Phosphatization of soft tissue in experiments and fossils. J. Geol. Soc. Lond. 1993, 150, 1035-1038. [CrossRef]

76. Wilson, P.; Parry, L.A.; Vinther, J.; Edgecomb, G.D. Unveiling biases in soft-tissue phosphatization: Extensive preservation of musculature in the Cretaceous (Cenomanian) polychaete Rollinschaeta myoplena (Annelida: Amphinomidae). Palaeontology 2016, 59, 463-479. [CrossRef]

77. Saggemann, J.; Bale, S.J.; Briggs, D.G.; Parkes, R.J. Controls on formation of authigentic minerals in association with decaying organic matter: An experimental approach. Geochim. Cosmochim. Acta 1999, 63, 1083-1095. [CrossRef]

78. Ballhaus, C.; Gee, C.T.; Bockrath, C.; Greef, K.; Mansekldt, T.; Rhede, D. The silicification of trees in volcanic ash-An experimental study. Geochim. Cosmochim. Acta 2012, 84, 62-74. [CrossRef]

79. Leo, R.F.; Barghoorn, E.S. Silicification of Wood. Bot. Mus. Leafl. Harv. Univ. 1976, 25, 1-47.

80. Zachos, J.C.; Pagani, M.; Sloan, L.; Billups, K.; Thomas, E. Trends, rhythms, and aberrations in global climate $65 \mathrm{Ma}$ to present. Science 2001, 292, 686-693. [CrossRef] [PubMed]

81. Graham, A. Late Cretaceous and Cenozoic History of North American Vegetation; Oxford University Press: New York, NY, USA, 1999.

(C) 2017 by the authors. Licensee MDPI, Basel, Switzerland. This article is an open access article distributed under the terms and conditions of the Creative Commons Attribution (CC BY) license (http:/ / creativecommons.org/licenses/by/4.0/). 